\title{
DISPERSION STUDY OF BURIED ELEMENTAL MERCURY
}

E. G. OREBAUGH and W. H. HALE, JR.

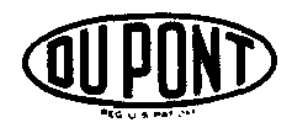

SAVANNAH RIVER LABORATORY AIKEN, SOUTH CAROLINA 29801 


\section{NOTICE}

This report was prepared as an account of work sponsored by the United States Government. Neither the United States nor the United States Energy Research and Development Administration, nor any of their contractors, subcontractors, or their employees, makes any warranty. express or implied, or assumes any lagel liability or responsibility for the accuracy, completeness or usefulness of any information, apparatus. product or process diselosed, or represents that its use would not infringe priverdy owned rights.

Printed in the United States of America

Available from

National Tochnical Information Service

U. S. Department of Commerce

5285 Port Royal Road

Springfield, Virginia 22161

Price: Printed Copy \$4.00; Microfiche \$2.25 


\section{4 \\ DP-1401 \\ UC-41}

\section{DISPERSION STUDY OF BURIED ELEMENTAL MERCURY}

by

E. G. Orebaugh and W. H. Hale, Jr.

Approved by

W. H. Hale, Jr., Research Manager

Separations Chemistry Division

Publication Date: July 1976

E. 1. DU PONT DE NEMOURS AND COMPANY SAVANNAH RIVER LABORATORY AIKEN, SOUTH CAROLINA 29801

PREPAREO FOR THE U.S. ENERGY RESEARCH AND DEVELOPMENT ADMINISTRATION UNDEA CONTAACT AT $\{07.2\}-1$ 


\section{ABSTRACT}

Waste elemental mercury disposed of by burial in trenches has been found to have no probable environmental effects. (This method of disposal has been discontinued.) Transport modes by which buried mercury would be expected to reach man in the environment were modeled mathematically using experimentally determined and estimated parameters. Calculations established that elemental mercury is the stable chemical form in the soil matrix. Consequently, only diffusion of mercury vapor to the atmosphere and transport of mercury in soil water to the water table merited consideration. Aqueous transport occurs by both dissolution of mercury in water (maximum $=57 \mathrm{ppb}$ ) and suspension of mercury on oxide colloids of iron and silicon in soil water (maximum $=6 \mathrm{ppm}$ ).

Modeling the system required consideration of geological, hydrological, and meteorological data as well as the experimental determination of mercury diffusivity in soil and aqueous solubility/suspension. Mathematical analysis considered countercurrent flux of gaseous diffusion of mercury vapor to the atmosphere and simultaneous dissolution in soil water. The distribution and physical integrity of individual burial units were factors in estimation of the various flux modes.

This study indicated that colloidal suspension is the dominant mode for transport of mercury from the burial site. By this means, a mercury flux of about $200 \mathrm{mg} / \mathrm{hr}$ from about 10 tons of buried mercury may enter the water table and travel horizontally, eventually exiting as surface water. As a worst case, this flux could contribute $20.2 \mathrm{ppb}$ to nearby Four Mile Creek, which is near the range of natural mercury levels in fresh water streams and lakes. 


\section{CONTENTS}

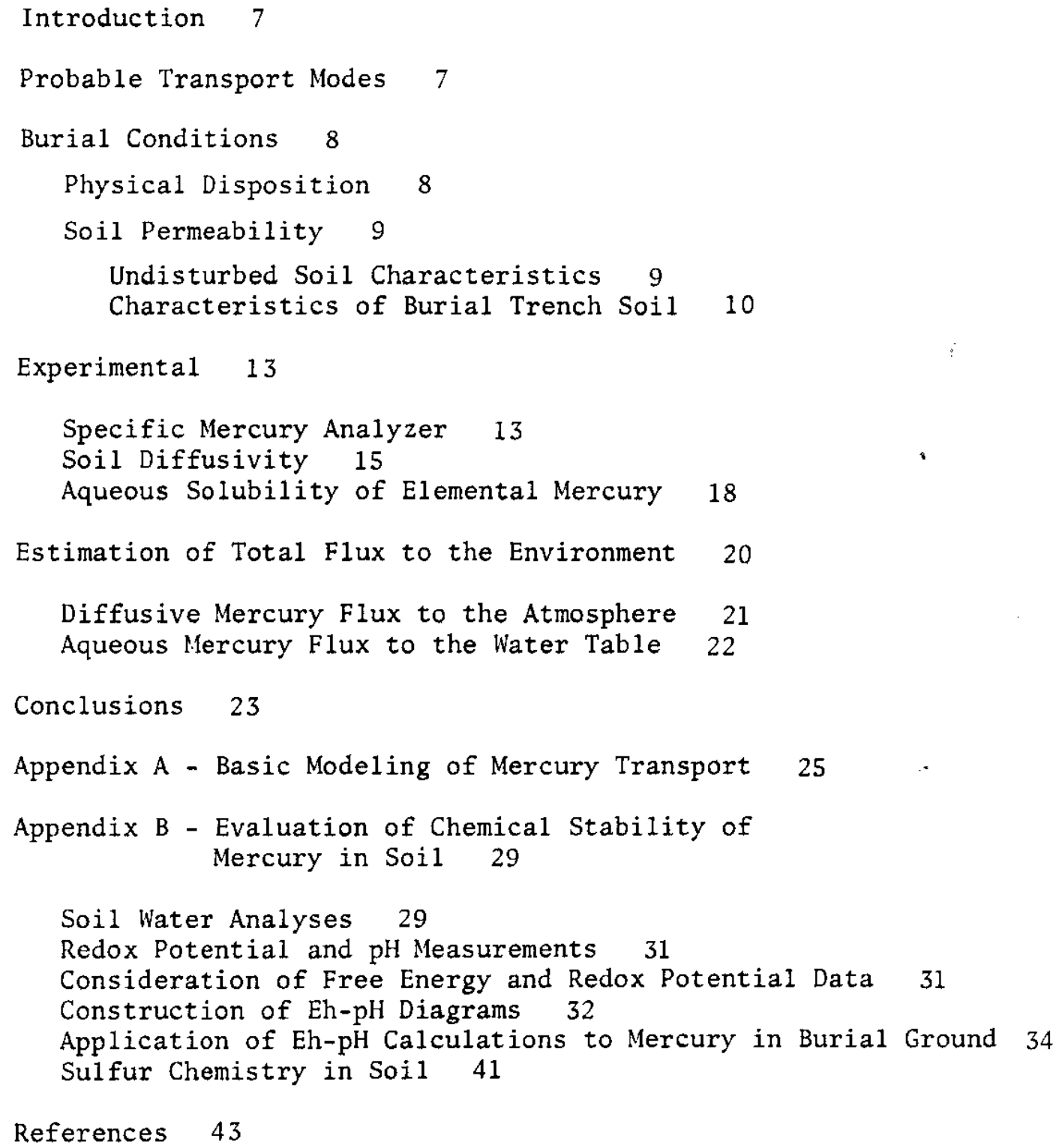




\section{LIST OF TABLES}

1 Observed Diffusion of Mercury

Vapor Through Moist Packed Soil 16

B-1 Analyses of Ground Water 30

B-2 Eh and pH Measurements in Burial

Ground Soil-Water System 31

B-3 Data for Mercury Eh-pH Diagrams 34

B-4 Summary of Calculations for Mercury Eh-pH Diagrams 37 


\section{LIST OF FIGURES}

1 Monthly Ranges of Water-Saturated

Zone Depths in Solid-Waste Trenches 11

2 Diffusive Flux of Mercury Vapor

as a Function of Soil Diffusivity and Soil Water Flux 12

3 Schematic Diagram of Mercury Analyzer 13

4 Calibration and Evaluation of Precision of Mercury Analyzer 14

$5 \quad$ Packed Soil Diffusion Cell 15

6 Effect of Soil Moisture on Mercury Diffusivity 17

7 Reduction-Aeration Accessory to Mercury Analyzer 18

A-1 Mathematical Model of Diffusion of Mercury From Soil to the Atmosphere 26

B-1 Eh-pH Diagram for Aqueous Systems Containing Sulfur 35

B-2 Eh-pH Diagram for Aqueous Systems of Mercury Containing 3.5 ppm Chlorine 38

B-3 Eh-pH Diagram for Aqueous Systems of Mercury Containing 10 ppm Chlorine and 10 ppm Sulfur

B-4 Eh-pH Diagram for Aqueous Systems of Mercury Containing $100 \mathrm{ppm}$ Chlorine and $100 \mathrm{ppm}$ Sulfur 


\section{DISPERSION STUDY OF BURIED ELEMENTAL MERCURY}

\section{INTRODUCTION}

This study concerns the evaluation of possible environmental consequences from burial of elemental mercury in soil at the SRP solid-waste burial ground. Since startup of the tritium production facilities at SRP, over 10 tons of waste elemental mercury have been buried in containers in trenches of the burial ground that are used for disposal of materials contaminated with low levels of beta-gamma radioactivity. Experimental information was needed to support the postulate that mercury so stored would not return to the biosphere at an undesirable rate.

The first step in this study was to determine the thermodynamically stable form of mercury in the soil-water system in which it is buried. After consideration of the soil redox. potential, $\mathrm{pH}$, and inorganic chloride and sulfate concentrations, it was conciuded that elemental mercury would be the stable form (see Appendix B). Studies were then undertaken to determine the rate of migration of elemental mercury from the burial ground.

\section{PROBABLE TRANSPORT MODES}

Two transport modes were initially envisioned that would allow mercury dispersal to the environment. These were: (1) evaporative diffusion of mercury vapor to the atmosphere through the soil overburden, and (2) dissolution-percolation of elemental mercury to the water table via a vertical soil-water flux. Experimental difficulties encountered while determining the aqueous solubility of elemental mercury showed that a third transport mode was possible. This mode allows the suspension of mercury by colloids of hydrated oxides of iron and silicon in soil water.

Parameters required to model the diffusion of mercury vapor to the atmosphere include the diffusion coefficient of gases through burial ground backfilled soil and the aqueous solubility of elemental mercury. The diffusion coefficient of a gas through the soil is a function of soil porosity and is independent of the diffusing gas. Though diffusivities have been measured with various gases under various conditions, direct measurement with mercury vapor and burial ground soil was desirable. Since diffusivity is a function of soil porosity, it is dependent upon the essentially constant bulk volume and the variable 
moisture content of the soil. Thus, diffusivities must be measured as a function of soil moisture to ensure valid application of the experimental data. Burial ground soil is predominantly sandy clay, with a water content at or near capillary saturation of 20 to 22 vol $\%$ water. ${ }^{1,2}$ Soil packed at 2100 psi containing $10 \mathrm{wt} \%$ water was shown to be equivalent to 20 vol\% water.

The aqueous solubility of mercury must be known to establish the equilibrium concentrations of mercury between the gaseous and aqueous phases in soil. The aqueous solubility of mercury in a soil-water flux impedes diffusion of mercury vapor to the atmosphere. Thus, the magnitude of the soil water flux must be estimated for the prevailing conditions. Finally, the variation of burial depth must be included in the mathematical modeling.

Modeling the transport of elemental mercury to the water table again requires knowledge of the soil-water flux and the aqueous solubility. In addition, however, colloidal suspension of mercury requires direct contact of the soil-water flux with elemental mercury. Thus, a "contact" model must be included in the basic modeling of the aqueous transport of mèrcury.

The basic modeling of the transport modes assumes: (1) uniform soil purosity from the deposition depth to the surface; (2) free air circulation at the soil surface with zero concentration of mercury vapor; (3) equilibrium conditions between mercury vapor and dissolved mercury; (4) time independent conditions; (5) a constant temperature of $20^{\circ} \mathrm{C}$; and (6) one-dimensional geometry.

Mathematical modeling of the transport modes described in Appendix $A$ is based on the parameters and assumptions discussed above. However, to arrive at an estimate of the annual or seasonal flux of mercury to the environment, other factors must be considered. These factors include the physical disposition of mercury in the soil, soil permeability to gases, and to soil water.

BURIAL CONDITIONS

Pilysical Disposition

The estimated 20,000 pounds of waste mercury in the burial ground is contained in 200 to 300 five-gallon steel cans each containing 2 or 3 liters ( 60 or 90 pounds) of mercury. The mercury was originally packaged in one-liter polyethylene bottles, which were doubly bagged in polyethylene before being placed in the cans. Since no specific instructions were issued 
concerning burial depth or location, the cans must be assumed to be randomly distributed both horizontally and vertically in the low-level beta-gamma trenches. Because of the large available area in the trenches, the cans may be assumed to be independent sources of mercury. The trenches are 20 feet deep with a minimum burial depth specification of 4 feet.

A possible mechanism for release of mercury to the soil is collapsing of the steel cans by the combined load of overburden and power machinery, with subsequent rupture of the polyethylene bottles and release from the polyethylene bagging. In this study, all mercury was assumed to be released to the soil.

The surface tension of mercury against water is quite high. This decreases the probability of infusion of mercury into the soil upon release from the ruptured burial package. The mercury would probably displace air in the available macro-fissures in the soil; however intrusion into smaller fissures is limited due to the small head pressure of mercury nodules. The minimum pore diameter accessible to a given head of mercury is approximately:

$$
\text { Pore Diameter }(\mathrm{cm})=\frac{0.13}{\text { mercury head pressure }(\mathrm{cm})} \text {. }
$$

Though the fissures accessible in loose-packed soil are inadequately modeled by circular pores, the few centimeters of head available from mercury in the crushed can will hardly cause extensive infusion into the soil. In short, radial dispersions of more than one meter from a unit burial of mercury waste are improbable. Thus, for purposes of total flux estimation, $3 \mathrm{~m}^{2}$ of dispersion area per burial unit is considered an upper limit.

Should the polyethylene packaging survive burial intact, its expected lifetime of greater than 100 years is sufficient time to permit complete disintegration of the steel can and the elimination (by settling) of all macro-fissures in the surrounding soil. This has the effect of limiting the infusion of mercury into soil to only a few centimeters outside its burial configuration.

\section{Soil Permeability}

\section{Undisturbed Soit Characteristics}

At SRP, undisturbed soil has been in a geologically stable condition for many millions of years. Soil water percolation has produced a highly leached soil of uniform porosity. Root systems of vegetation penetrate only a few feet, causing significant variation in porosity and moisture content in that depth. The soil beneath the root zone is characterized as capillary-saturated to a uniform and stable moisture content (20 to 22 vol $\%$ ).

$$
-9-
$$


The water table at the burial ground varies seasonally about a mean depth of 30 feet. During years of normal rainfall, the water tables begin to rise during December and January, reaching a peak during March or Apri1, followed by a gradual decline during the remainder of the year. The amplitude of these "normal" variations is typically about 6 inches. The normal annual ground water recharge, estimated according to modeling by the U. S. River Forecasting Service, is of the order of 10 to 15 inches of equivalent precipitation per year. This recharge occurs during the same time period as the measured rise in the burial ground water table and is a direct result of the seasonal variation of soilwater flux.

The seasonal variation of normal soil-water fluxes can also be estimated by the difference between the precipitation rate and the transpiration-evaporation rate. A standard model for transpiration-evaporation rates is the "open-pan evaporation" data collected at many locations throughout the country. When the open-pan evaporation data are adjusted by a constant factor to simulate the transpiration-evaporation rates in this modeling of the soil-water flux, the expected seasonal variations are obtained, i.e., a 4-month period of 2.5-in./mo and an 8-month period of zero flux. This model correlates well with other information on soil-water fluxes.

This seasonal variation results from the depletion of soil moisture in the root zone by transpiration of vegetation during the active growing season. As long as the rainfall is insufficient to completely recharge the soil to capillary saturation, no hydraulic head is developed and no soil-water flux to the water table will occur. In the fall, the transpiration and evaporation rates decrease allowing a gradual capillary saturation so that winter rains result in a net soil-water flux to the water table. The abruptness of the seasonal change is caused by normally lighter precipitation in the spring and fall.

\section{Characteristics of Burial Trench Soil}

The backfilled soil in burial trenches has different physical characteristics than those of undisturbed soil. The porosity of backfilled soil will probably never decrease to that of the surrounding soils. Because of its higher porosity, trench soil would be expected to collect surface runoff from surrounding undisturbed soils. Thus, modeling of soil-water flux based upon natural undisturbed soils (10 to $15 \mathrm{in} / \mathrm{yr}$ ) would not be applicable to trench soil. However, the more-permeable trench soil extends only 20 feet to the bottom of the trench, where natural soil of lower permeability limits the water flux to a lower value. This condition results in ephemeral perched water tables in the trenches. These ephemeral regions of saturated soil have been studied since 1969 in connection with their effect on leaching of buried radioactivity. 
The transitory nature of the water tables in the trenches is illustrated in Figure 1, which shows monthly ranges of watersaturated zone depths for Test Well 19. This test well is located at the upgrade end of a low-level beta-gamma trench near the boundary of the burial ground. Because this test well site is subject to larger surface runoff than the average trench site, it is a good model for the study of trench soil-water flux.

Though Figure 1 shows only the minimum and maximum saturation depths measured during monthly periods, the measurements were taken weekly. Summation of all the saturation depths recorded during the year shows that a minimum of 34 feet of soil was saturated by the trench soil-water flux.

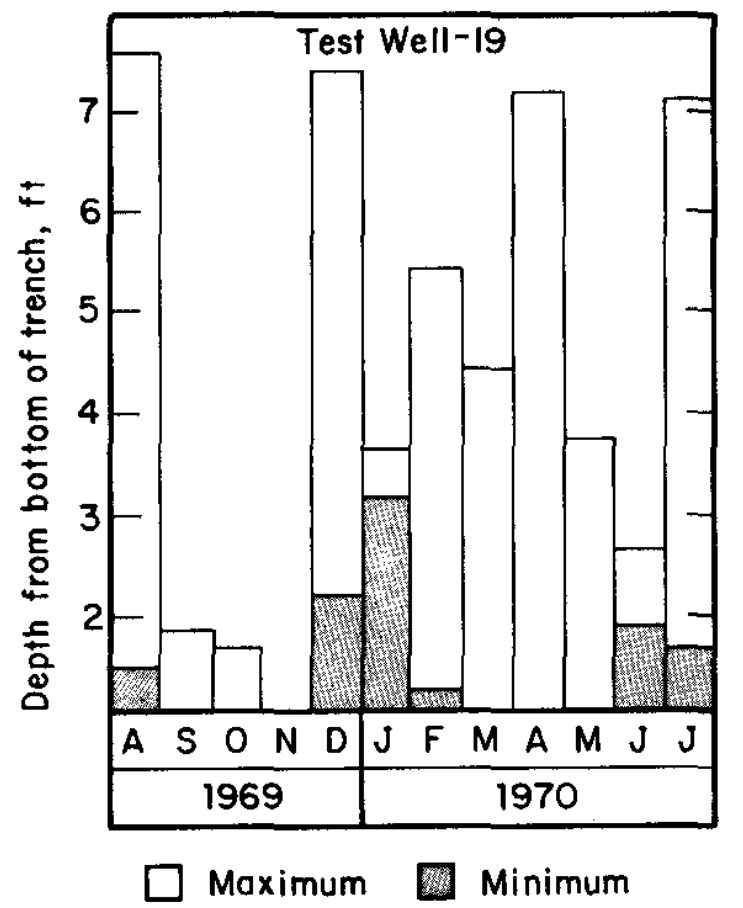

FIGURE 1. Monthly Ranges of Water-Saturated Zone Depths in Solid-Waste Trenches

An estimate of the trench soil-water flux equal to $8 \mathrm{ft} / \mathrm{yr}$ is based on the integrated water-saturated soil depth and the trench density in the burial ground. Thus the measured $34 \mathrm{ft} / \mathrm{yr}$ saturation depth is equivalent to about $7 \mathrm{ft}$ of water based on a $20 \%$ porosity for unsaturated soil. The data show that these saturated zones can easily accumulate and dissipate between measurements. Thus the actual flux for Test Well 19 was probably larger than $7 \mathrm{ft} / \mathrm{yr}$. This amount of water is accumulated not only from the direct rainfall ( $4 \mathrm{ft} / \mathrm{yr}$ ) but also from the run-off of undisturbed soil between trenches and from soil outside the 
burial ground. Since the trenches occupy $50 \%$ of the surface area and absorb rainfall much more rapidly than undisturbed soil, then an average trench, not subject to run-off from outside the area, would absorb about $8 \mathrm{ft} / \mathrm{yr}$. Moreover, this flux would follow the normal rainfall pattern rather than the highly seasonal pattern of normal soil-water fluxes. Though the instantaneous flux varies greatly, the mean hourly flux by this estimate is 0.027 $\mathrm{cm} / \mathrm{hr}$ or some 10 times greater than that of normal soils.

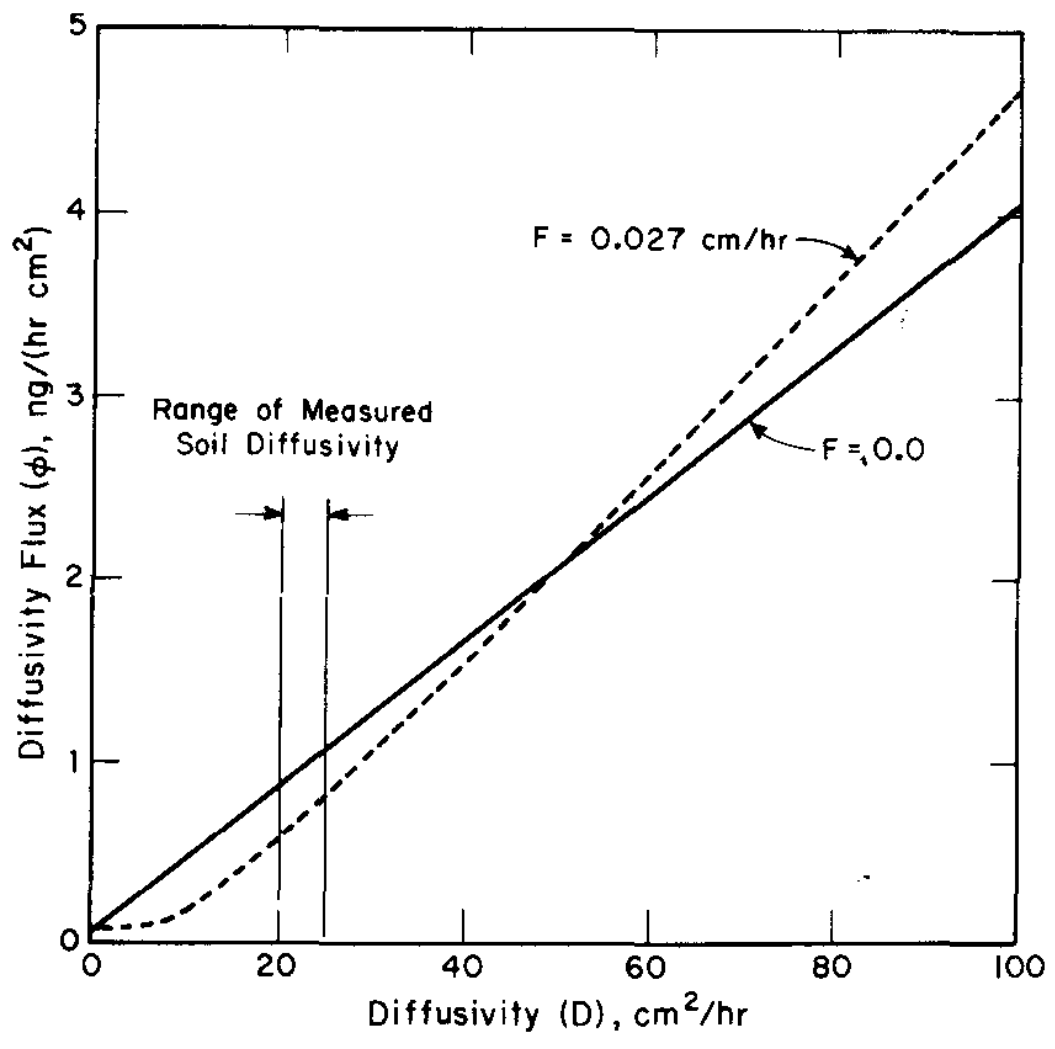

FIGURE 2. Diffusive Flux of Mercury Vapor as a Function of Soil Diffusivity and Soil Water Flux

The greatly enhanced soil-water flux estimated above will not only affect the aqueous transport of mercury but also the diffusion of mercury vapor to the atmosphere. The effect on the aqueous transport is direct, that is, doubling the soil-water flux doubles the mercury flux. However, the effect on mercury diffusion to the atmosphere is much more complicated. Figure 2 illustrates the variation of modeled vapor diffusion flux as a function of soil diffusivity and soil-water flux. The limiting 
condition of a zero soil-water flux is shown for reference. The range of diffusivity, $20 \leq D \leq 26$, found for soil of normal moisture content is of particular interest. Note that the estimated mean soil water flux is sufficient to completely suppress mercury diffusion in soils of low diffusivity. Because of this, vapor diffusion is limited to trench soil. Since instantaneous soilwater fluxes may be many times the mean value, the diffusive flux to the atmosphere must be assumed to be near zero during periods of high soil water flux. In any event, the maximum diffusive flux through normal SRP soil is obtained with zero soil-water flux.

\section{EXPERIMENTAL}

\section{Specific Mercury Analyzer}

The main analytical tool used in the experimental aspects of this study was a specific mercury analyzer based upon the atomic fluorescence of mercury vapor when excited by $2537 \AA$ radiation. This apparatus was assemblied following the design of Muscat, et al.,, 5 as diagrammed in Figure 3 . This versatile design was chosen because of its capability for analyzing mercury

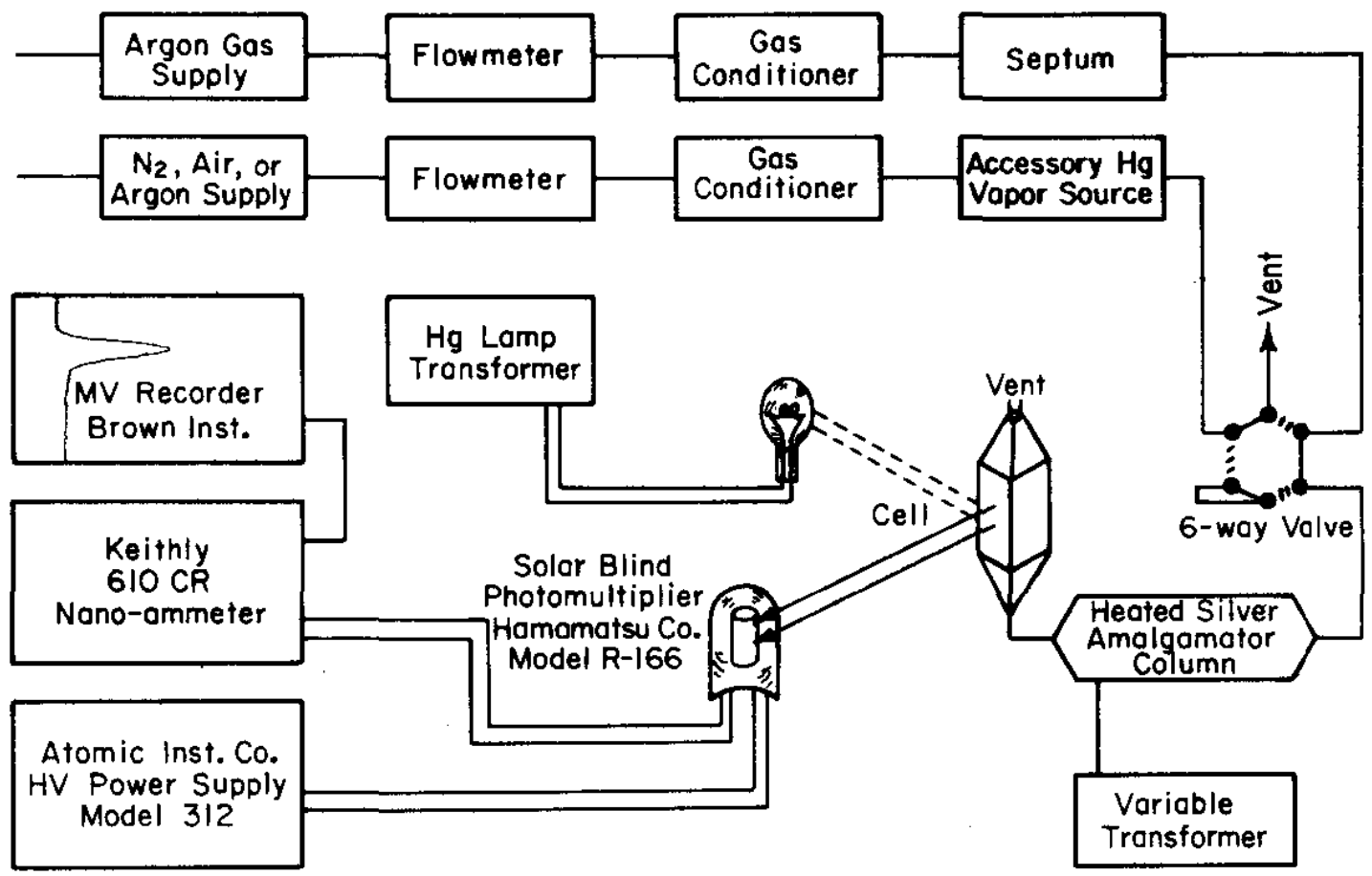

FIGURE 3. Schematic Diagram of Mercury Analyzer 
concentrations in air or in aqueous solution very simply and rapidly. Initial calibration and evaluation of precision using $25^{\circ} \mathrm{C}$ mercury vapor is shown in Figure 4. This level of precision was typical of the diffusion study. In addition, solutions of mercury salts can be analyzed by reduction with stannous chloride followed by aeration to evolve mercury vapor. The precision observed with aeration was about $1 \%$ relative at mid-range. Indeed, any scheme in which mercury can be converted to elemental vapor at atmospheric pressure can be used as an accessory to the basic apparatus.

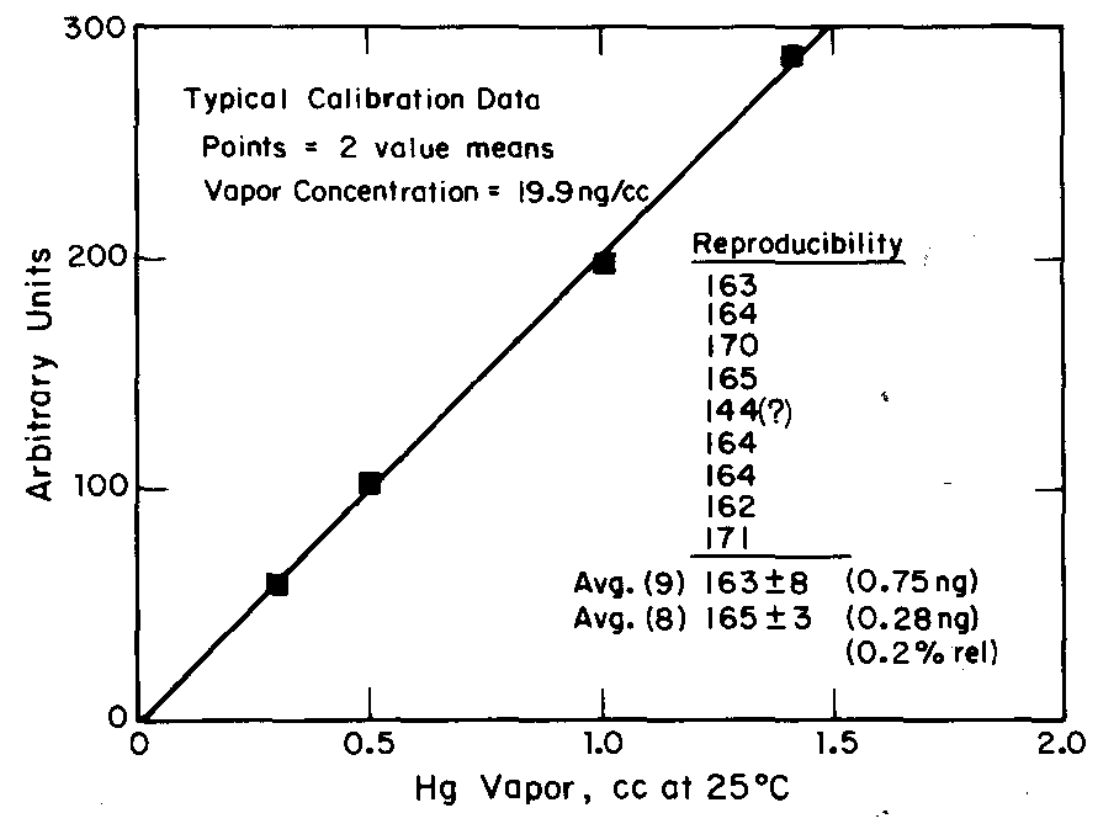

FIGURE 4. Calibration and Evaluation of Precision of Mercury Analyzer

Operation of the mercury analyzer depends upon sweeping mercury vapor from the accessory vapor source into an amalgamator column in which the mercury vapor is quantitatively absorbed on a silver wool packing. After a sufficient sweep time, the amalgamator column is heated rapidly to release the absorbed mercury into an argon stream. This integrated plug of mercury vapor passes through the fluorescence cell producing a recorded signal which is proportional to the integrated mass of mercury sampled. 


\section{Soil Diffusivity}

To measure the diffusivity of mercury vapor through soil samples, the soil diffusion cell shown in Figure 5 was constructed. This diffusion cell contains a strong sintered glass frit capable of withstanding a 40-pound load without rupture. Thus, when soil was packed into the cavity with a 3/4-in. ram at about 40 pounds of pressure, approximately 100 psi was applied to attain normal soil density. Though not used in this study, the diffusivity of "undisturbed" soil samples could also be measured by caulking the crevice between the soil plug and the cell wall with a viscous grease. The volume of the cell is minimized by the inverted dome on the diffusion cell. This ensures rapid transfer of mercury vapor from the cell.

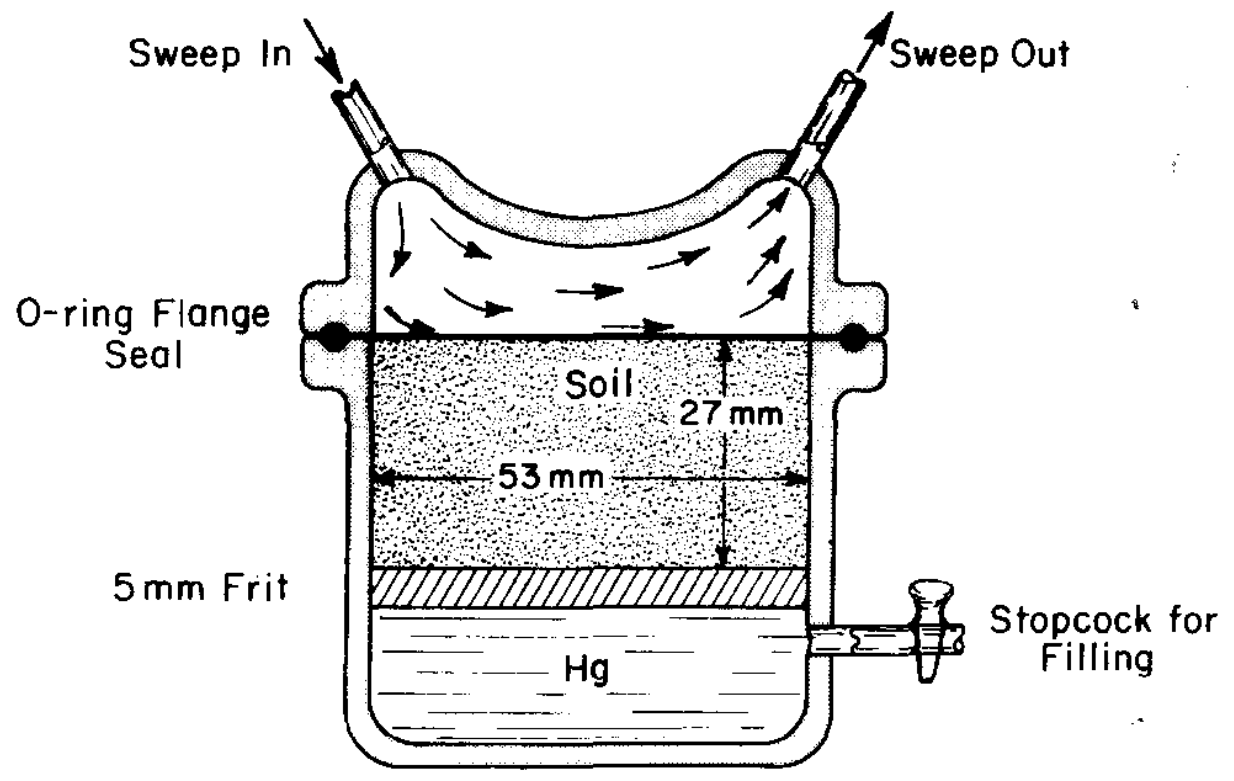

FIGURE 5. Packed Soil Diffusion Cell

Diffusivities were measured by establishing a time-independent gradient of mercury vapor across the soil plug in the apparatus. This was achieved by continuously passing mercury-free air across the soil-air interface. Mercury in contact with the glass frit provided a constant supply of mercury vapor at a concentration of $19.9 \mathrm{ng} / \mathrm{cc}$ at the standard experimental temperature of $25^{\circ} \mathrm{C}$. Changes in soil moisture content were suppressed by presaturating the sweep air at ambient temperature with water vapor before entering the diffusion cell. Because soil moisture concentration may have varied slightly during the several-day equilibration period, the moisture content was gravimetrically determined at the end of each measurement. 
Mercury flux in the diffusion cell was easily determined by switching the sampling valve to the sampling position for known periods of 5 to 60 seconds. The integrated mass of mercury was analyzed by calibration against saturated mercury vapor at known temperatures. Saturated mercury vapor was injected at the septum in the argon sweep stream by a calibrated gas syringe. As only a single concentration of mercury vapor was used, the calibration parameters were determined from various integrations of the diffusion cell flux. Table 1 summarizes the mercury flux observed with soils of various moisture contents.

\section{TABLE 1}

\section{Observed Diffusion of Mercury Vapor Through Moist, Packed Soil}

\begin{tabular}{llll}
$\begin{array}{llll}\text { Moisture in Ceiz } \\
\text { at End of Test, } \\
\text { wt \% }\end{array}$ & \multicolumn{3}{c}{ Flux of Mercury Vapor, ng/sec } \\
\cline { 2 - 3 } 2.5 & Temp., ${ }^{\circ} \mathrm{C}$ & Observed & Normazized to $25^{\circ} \mathrm{C}$ \\
& 25.8 & 3.46 & 3.24 \\
& 25.9 & 3.23 & 3.00 \\
& 25.7 & 3.07 & 2.90 \\
5.1 & 24.5 & 2.83 & 2.95 \\
& 24.6 & 2.91 & 3.02 \\
7.9 & 25.0 & 1.33 & 1.33 \\
& 25.5 & 1.42 & 1.36 \\
& 26.0 & 1.41 & 1.30 \\
9.5 & 24.5 & 0.85 & 0.89 \\
& 24.5 & 0.86 & 0.90
\end{tabular}

The mercury vapor flux data corrected for vapor pressure as a function of temperature are plotted versus the analyzed moisture content in Figure 6 . The non-1inear relationship is expected when one considers that the first few percent moisture added to dry soil is surface-absorbed and would have little effect upon the porosity. However, the capillary capacity is reached at about $10 \mathrm{wt} \%$, so that the rapid change in porosity between 5 and $10 \mathrm{wt} \%$ is expected. Experimental attempts to measure diffusivity in the region from 5 to $8 \%$ moisture were marked by highly erratic results. These erratic results were caused by 


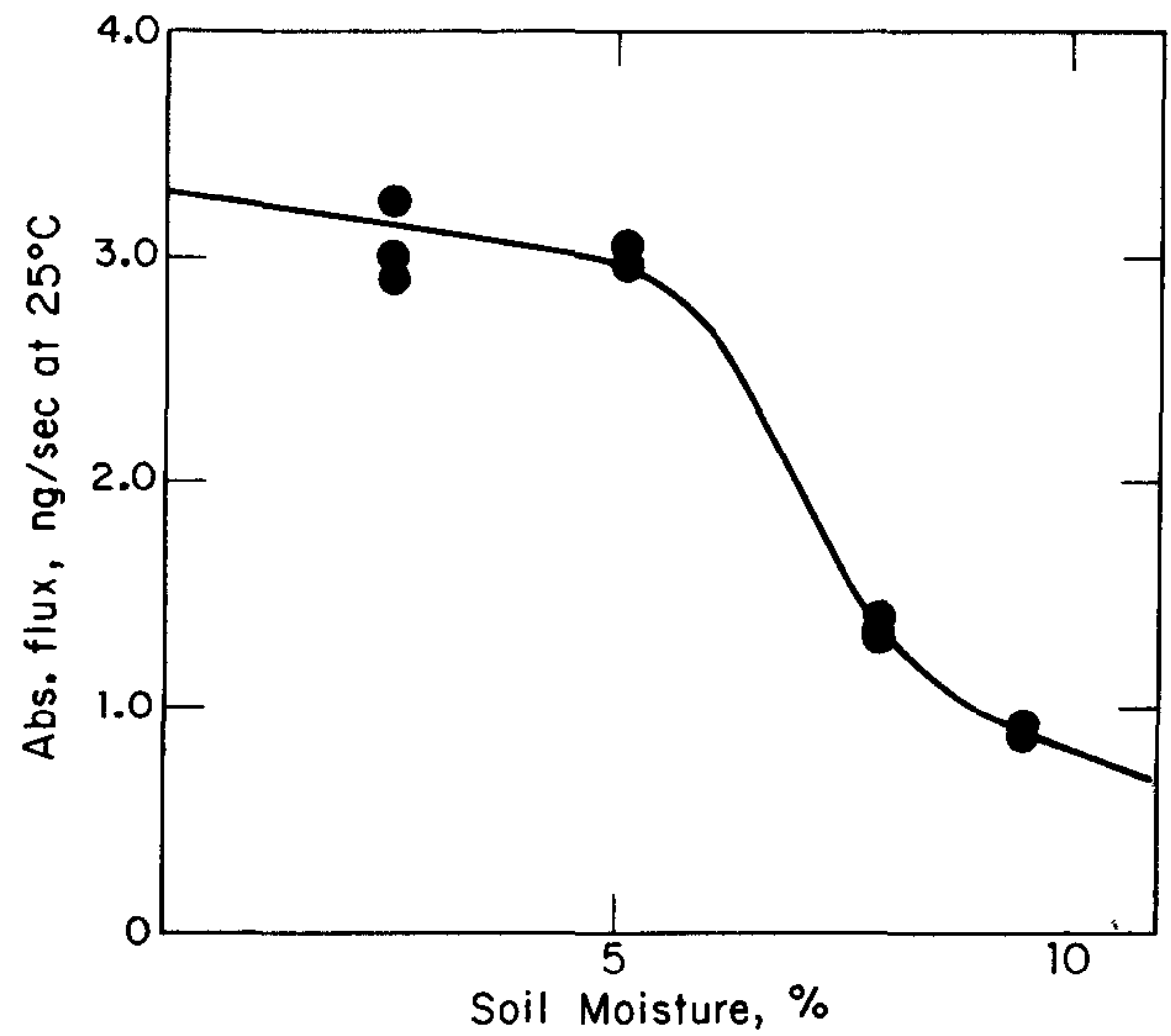

FIGURE 6. Effect of Soil Moisture on Mercury Diffusivity

soil moisture variation in the region where moisture held by capillary tension sharply decreased the number and size of intergranular diffusion channels. The greater variation in data at $2.5 \%$ moisture level was caused by problems associated with packing dry soil.

The diffusion flux data reported above were used to obtain the diffusion coefficient (or diffusivity), $D$, by the following equation:

$$
\frac{d Q}{d t}=-D\left(\frac{d C}{d X}\right) d y d z
$$

where dQ is the amount of mercury vapor passing through an area dydz in the direction of $X$ in a time dt, and where $\mathrm{dC} / \mathrm{dX}$ is the rate of increase of vapor concentration in the direction of $x$. The quantities in the equation are readily identified with the experimental conditions. $\mathrm{dQ} / \mathrm{dt}$ is the observed diffusion rate $\left(\emptyset_{\text {exp }}\right)$ for the apparatus whose cross-sectional area of $22.1 \mathrm{~cm}^{2}$ is $\mathrm{dydz}$. In the experimental arrangement, the $3.2-\mathrm{cm}-\mathrm{deep}$ soil 
plug established the concentration gradient $(\mathrm{dC} / \mathrm{dX})$ for a $25^{\circ} \mathrm{C}$ vapor concentration of $19.9 \mathrm{ng} / \mathrm{cc}$. These various constants and parameters can be combined into a single factor (26.2) which when multiplied by the observed diffusion flux (in $\mathrm{ng} / \mathrm{sec}$ ) yields the diffusivity in $\mathrm{cm}^{2} / \mathrm{hr}$

$$
D=26.2 \emptyset_{\exp } \mathrm{cm}^{2} / \mathrm{hr}
$$

From Figure $6, \emptyset_{\text {exp }}$ is $0.8 \mathrm{ng} / \mathrm{sec}$ for soil containing 10 wt moisture.

In conclusion, while capillary-saturated, packed, moist soil (10 wt $\%$ ) has a coefficient of diffusion of approximately $21 \mathrm{~cm}^{2} / \mathrm{hr}$, dry soil has approximately 4 times this diffusivity. Thus, with only about half of the intergranular void space of the moist soil filled with water under capillary-saturated conditions, the available diffusion paths are greatly decreased.

\section{Aqueous Solubility of Elemental Mercury}

A reduction-aeration accessory (Figure 7) to the mercury analyzer was constructed ${ }^{5}$ to determine the aqueous solubility of elemental mercury. Initial tests indicated that full compatibility existed between chemical standards and calibration with mercury vapor. However, since solutions would be used in the solubility study, calibration with aqueous mercury salt standards was adopted as the general practice. Because of the simple nature of the solutions analyzed, an abbreviated procedure

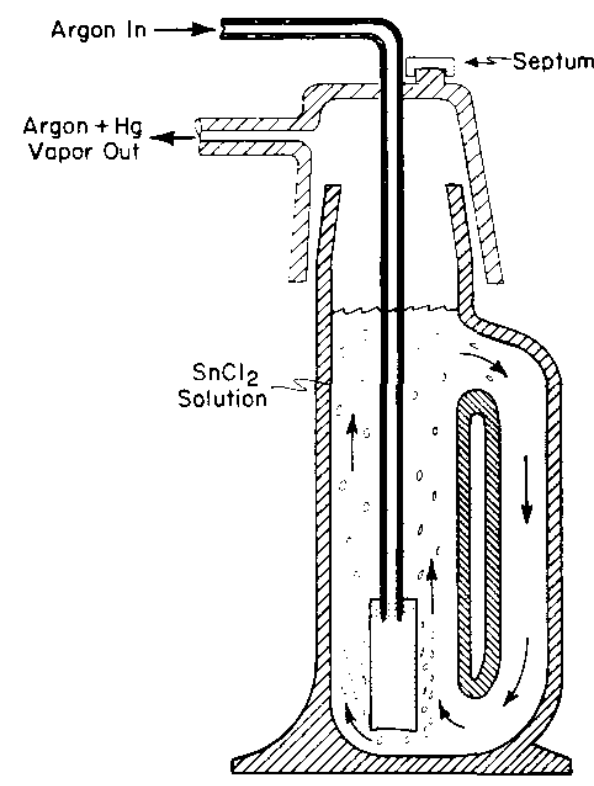

FIGURE 7. Reduction-Aeration Accessory to Mercury Analyzer 
was used in most of this work. In this procedure, the aeration bottle was filled with a nitric acid solution of stannous chloride into which aliquots of the sample were injected with a calibrated syringe.

Though no reaction of elemental mercury with soil or soil water was anticipated, since mercury is chemically stable in the soil, it was desirable to verify its solubility experimentally. New data by Onat ${ }^{6}$ on the solubility of elemental mercury at various temperatures were extrapolated to predict a concentration of about $60 \mathrm{ppb}$. However, initial analysis of a mercury-soi1water equilibrium experiment indicated greater than $2 \mathrm{ppm}$ elemental mercury in the supernate phase. This high result required verification of the aqueous solubility of mercury.

Following Onat's procedure, deionized water was boiled to expel absorbed gases and cooled under nitrogen. Mercury was equilibrated with the cooled water in a nitrogen atmosphere. Analysis showed about 1 ppm elemental mercury content. Repeated attempts always resulted in apparent solubilities several times the reported value. ${ }^{6}$ The presence of mercury in colloidal form was investigated by applying the Tyndall effect. Not only was a Tyndall beam found in the aqueous mercury solution, but also in the degassed, deionized water. Examination of un-degassed water clearly indicated that slight attack of g1ass lab-ware had occurred. Onat's data ${ }^{6}$ were verified when colloid-free water was equilibrated with mercury in plastic lab-ware. The experimental value obtained at $23.0^{\circ} \mathrm{C}$ was $54.3 \mathrm{ppb}( \pm 2 \%)$ compared to $56.5 \mathrm{ppb}$ extrapolated from Onat's work. The agreement is satisfactory when allowances for experimental and extrapolation errors are made.

The suspension of elemental mercury by silica colloids led to additional experiments which showed similar behavior by ferric hydroxide colloids, another colloidal component of soil water. Direct equilibration with composite ground water samples caused suspension of mercury at concentrations of up to $6 \mathrm{ppm}$. These water samples were taken from the surface of the water table at several well sites in the burial ground.

Another experiment confirmed that colloids did not sorb mercury from solution. Colloidal water was contacted with saturated mercury vapor for several days. The aqueous mercury concentration increased to near the literature value $(60 \mathrm{ppb})$ but did not exceed it. These results showed that mercury was transferred from the vapor to the aqueous phase, but mercury did not transfer from the aqueous phase to the colloids. 
Physical agitation of the mercury surface by stirring during equilibration was not responsible for the colloidal suspension. This was demonstrated when colloidal suspension occurred in an equilibration in which water was allowed to flow across the still surface of liquid mercury. Thus, colloidal suspension of elemental mercury in water requires direct contact of the aqueous and Iiquid mercury phases and is independent of physical disintegration of the mercury surface. No quantitative correlations were attempted to relate the maximum suspended mercury concentration to colloidal concentration.

Two experiments were performed to determine whether interaction, i.e., retardation, occurred between aqueous mercury or suspended mercury and the soil. For aqueous mercury, adsorption on the soil would retard the "front" of a plug flow of aqueous solution. For colloidally suspended mercury, any attraction between the soil and the colloids would allow a front of aqueous mercury to advance ahead of the colloidal front.

In the first experiment, an aqueous solution of about $40 \mathrm{ppb}$ mercury was pumped into a small (24 cc) column of soil. The column effluent was sampled after continuous flow was established. After about $6 \mathrm{ml}$ of effluent were forced from the colum, the mercury concentration increased to its input concentration (within experimental error). Since the soil initially contained about $5 \mathrm{ml}$ of water (based on $20 \mathrm{vol} \%$ ), the aqueous solution apparently displaced the original soil moisture under conditions of plug flow. From this experiment, we concluded that any interaction of aqueous mercury with soil was very small.

In the second experiment, the same column wars repacked with soil and flushed with water at $20 \mathrm{ml} / \mathrm{hr}$ for 2 days in order to decrease the natural colloidal content. Then a colloidal suspension of mercury was pumped into the column, and sampling for mercury analysis began on a six-minute cycle. When the mercury front appeared, the concentration changed from zero to nearly $400 \mathrm{ppb}$, the input concentration. Though a small advance front of aqueous mercury could have been missed in this sampling cycle, the evidence indicated that any soil-colloid interaction was also quite small.

\section{ESTIMATION OF TOTAL FLUX TO THE ENVIRONMENT}

Estimation of the total probable maximum flux to the environment was made for each of the identified transport modes. Estimates for the various modes do not have equal reliability because of the uncertainty of various parameters required in their computation. 
Diffusive Mercury Flux to the Atmosphere

Diffusive flux to the atmosphere is computed below according to the most probable values for the various parameters discussed in the previous sections. The soil water flux (F) was estimated earlier ( $\mathrm{p} \mathrm{12}$ ) to be $0.027 \mathrm{~cm} / \mathrm{hr}$; however, the instantaneous flux values may range from zero to 100 times this value. The value of $26 \mathrm{~cm}^{2} / \mathrm{hr}$ used for the diffusion coefficient (D) is the upper limit of the experimental values obtained with moist soil typical of the burial ground trenches.

The burial depths $\left(x_{0}\right)$ of the mercury deposits are assumed to be uniformly distributed between $150 \mathrm{~cm}$ and $600 \mathrm{~cm}$. Since diffusion to the atmosphere is not linear with burial depth, the average flux value $(\bar{\phi})$ must be obtained by integration as follows:

$$
\bar{\phi}=\int_{150}^{600} \phi d x / \int_{150}^{600} d x
$$

Using the expression for the modeled flux given in Appendix A,

$$
\phi=\frac{4.05 \mathrm{FC}_{0}}{1-\exp \left(-4.05 \mathrm{FX}_{\mathrm{o}} / \mathrm{D}\right)}
$$

where $C_{O}$ is the equilibrium mercury vapor pressure. The average flux becomes:

$$
\begin{aligned}
& \bar{\phi}=-4.05 F C_{0} \int_{150}^{600} \frac{\mathrm{dX}}{-1+\exp (-4.05 \mathrm{FX} / \mathrm{D})} / \int_{150}^{600} \mathrm{dX} \\
& \Phi=\frac{-4.05 \mathrm{FC}_{\mathrm{o}}}{(600-150)}\left[\begin{array}{c}
600 \\
150
\end{array}\right.
\end{aligned}
$$

For $F=-0.027 \mathrm{~cm} / \mathrm{hr}^{*}$ and $D=26 \mathrm{~cm}^{2} / \mathrm{hr}, \bar{\phi}$ equals $0.51 \mathrm{ng} / \mathrm{hr}-\mathrm{cm}^{2}$. This average flux is approximately $38 \%$ greater than that which would be computed from the mean burial depth. The calculated effective burial depth is $245 \mathrm{~cm}$.

* Mathematical derivation requires $F$ to be negative for compatibility with assumed coordinates. 
Since each of the 300 burial units is assumed to contribute a maximum effective area of one-meter radius, the total area available for diffusion is $300 \pi(1 \mathrm{~m})^{2}$, or $9.4 \times 10^{6} \mathrm{~cm}^{2}$. Thus, the total flux $(\phi)$ to the atmosphere is $5 \mathrm{mg} / \mathrm{hr}$.

Aqueous Mercury Flux to the Water Table

Aqueous mercury flux to the water table is best computed separately for the more reliable estimate of the soluble mercury flux and the morc speculative estimate of the flux of colloidaliy suspended mercury. Computation of the soluble aqueous flux is more reliable because, like the diffusion flux, it does not depend upon the assumed effective area. Thus, the aqueous mercury flux $(\phi)$ is simply the product of the effective area $\left(9.0 \times 10^{6} \mathrm{~cm}^{2}\right)$, the average soil water flux $(0.027 \mathrm{~cm} / \mathrm{hr})$, and the saturation concentration $\left(53 \mathrm{ng} / \mathrm{cm}^{3}\right)$ :

$$
\begin{aligned}
\phi_{\text {aqueous }} & =9.0 \times 10^{6} \times 0.027 \times 53=13 \times 10^{6} \mathrm{ng} / \mathrm{hr} \\
& =13 \mathrm{mg} / \mathrm{hr}
\end{aligned}
$$

This is also a maximum probable value since, during periods of high soil water flux, equilibrium conditions may be sufficiently upset that saturation may not be achieved upon reaching the burial depth.

The total flux of colloidally suspended mercury entering the water table must be computed from an assumed physical dispersion of the mercury. In modeling the colloidal suspension mode, the assumption was made that only colloids carried by the soil-water flux within a few soil grain diameters of a mercury surface would be effective in extracting mercury. Also, on $1 y$ the perimeter of a mercury nodule was proposed to present an effective contact with colloids in the soil-water flux. The horizonal travel of colloids in a vertical water flux is small, estimated to be $0.1 \mathrm{~cm}$, resulting from flow around soil grains. Estimates of $0.1 \mathrm{~cm}$ for the maximum effective horizontal trave 1 and $0.054 \mathrm{~cm} / \mathrm{hr}$ for the compressed flux rate at the nodule perimeter are probably accurate within a factor of 3 . The remaining parameter required to estimate mercury in the soil-water flux is the sum of all nodule perimeters.

The only way to obtain a realistic measure of the actual dispersion of mercury in the soil would be to dig up a deposit and make measurements. These measurements could be made by $x$-ray examination of sections of the impregnated soil. In the absence of evidence for determining the actual dispersion, probable minimum and maximum dispersals must be assumed so that an estimate may be made. Minimal dispersal was modeled by $1-\mathrm{cm}$-radius spherical nodules of mercury, while the maximum dispersal was modeled by 1 -mm-radius spheres. 
The minimum dispersal of 20,000 pounds of mercury would result in $1.7 \times 10^{5}$ spheres. The sum of the perimeters of these spheres would be $1.1 \times 10^{6} \mathrm{~cm}$. At $0.1-\mathrm{cm}$ horizonal travel of the colloids, the effective suspension area is $1.1 \times 10^{5} \mathrm{~cm}^{2}$. If the maximum $6 \mathrm{ppm}$ of suspended mercury found in the experimental work is used, the total minimum flux is:

$$
\begin{aligned}
\phi_{\text {colloidal }} & =(0.054 \mathrm{~cm} / \mathrm{hr})\left(6 \times 10^{-6} \mathrm{~g} / \mathrm{cm}^{3}\right)\left(1.1 \times 10^{5} \mathrm{~cm}^{2}\right) \\
\text { minimum estimate } & =0.035 \mathrm{~g} / \mathrm{hr}=35 \mathrm{mg} / \mathrm{hr}
\end{aligned}
$$

The maximum dispersal would result in $1.7 \times 10^{8}$ spheres wih a total perimeter sum of $1.1 \times 10^{8} \mathrm{~cm}$, and a resulting area of $1.1 \times 10^{7} \mathrm{~cm}^{2}$. Using the same values for soil water flux and colloidal concentration, the total maximum flux is:

$$
\begin{aligned}
\phi_{\text {colloidal }} & \left.=(0.054): 6 \times 10^{-6}\right)\left(1.1 \times 10^{7}\right) \\
\text { maximum estimate } & =3.5 \mathrm{~g} / \mathrm{hr} \\
& =3,500 \mathrm{mg} / \mathrm{hr}
\end{aligned}
$$

Because both the minimum and maximum dispersions estimated above are quite reasonable, the total colloidal flux is probably an intermediate value. In discussing the probable physical disposition of the mercury, rupture was considered to be nearly certain. If we assume that the burial packages had ruptured and released mercury into the soil resulting in a dispersal that could be modeled by $5 \%$ (maximum) and $95 \%$ (minimum), then the total estimated flux is:

$$
\begin{aligned}
\phi & =(35 \times 0.95)+(3500 \times 0.05) \\
& =206 \mathrm{mg} / \mathrm{hr}
\end{aligned}
$$

\section{CONCLUSIONS}

Water passing through the burial ground to Four Mile Creek could transport mercury at a rate of $2219 \mathrm{mg} / \mathrm{hr}(206 \mathrm{mg} / \mathrm{hr}$ on colloidal suspensions of iron and silicon oxides, and $13 \mathrm{mg} / \mathrm{hr}$ of dissolved mercury). Thus, the contribution to the mercury level of Four Mile Creek (average flow of $10^{6}$ liters/hr) is $\sim 0.2 \mathrm{ppb}$.

This value compares to $0.03 \mathrm{ppb}$ given as the natural average mercury concentration in streams, rivers and lakes, ${ }^{7}$ and the U. S. Public Health Service recommendation of $5 \mathrm{ppb}$ for drinking water. Thus, there is apparently no significant environmental impact on surface waters in the area of the burial ground. However, the indiscriminate use of shallow well water in the vicinity of the burial ground should be discouraged since local water strata may contain concentrations of mercury above the 5 ppb recommended as the limit for drinking water.

$$
-2.3-
$$


Vapor transport to the atmosphere is estimated at $5 \mathrm{mg} / \mathrm{hr}$. This flux is considered insufficient to have any environmental impact because of the free circulation of air in the burial site. 


\section{APPENDIX A - BASIC MODELING OF MERCURY TRANSPORT}

In modeling the diffusion of mercury vapor to the atmosphere, both the diffusing mercury vapor and the soil-water flux must be considered. Under equilibrium conditions, the degree of saturation is assumed to be equal for both gaseous and dissolved mercury. This allows one to describe the concentration of dissolved mercury in the aqueous phase as a function of the concentration in the gaseous phase at any point because activities are equal at the assumed conditions. Since the model will assume a mean soil temperature of $20^{\circ} \mathrm{C}$, the ratio of aqueous to gaseous saturation concentrations is $52.7 / 13.0=4.05$. Figure A-1 illustrates the various mathematical expressions for mercury fluxes entering and leaving a differential volume element in the soil. The mathematical description of the system demands a mass balance, hence:

$$
\begin{aligned}
& \text { input }=\text { output } \\
& -D\left(\frac{d C}{d X}\right)+4.05 F\left(C+\frac{d C}{d X}\right)=4.05 F C-D\left[\frac{d C}{d X}+\frac{d^{2} C}{d X^{2}}\right]
\end{aligned}
$$

or

$$
4.05 F\left(\frac{d C}{d X}\right)+D\left(\frac{d^{2} C}{d x^{2}}\right)=0
$$

This differential equation has a general solution:

$$
C=k_{1}+\left(\frac{k_{2} D}{4.05 F}\right) \exp (4.05 F X / D)
$$

The integration constants of the general solution may be evaluated by considering the boundary conditions at the mercury-soil interface and at the soil surface. Thus:

$$
\begin{aligned}
& \text { at } X=0, C=C_{0}=13.0 \mathrm{ng} / \mathrm{cc} ; \\
& C_{0}=k_{1}+k_{2} D / 4.05 \mathrm{~F} \\
& \text { at } X=X_{0}=X_{\max }, C=0.0 ; \\
& 0=k_{1}+\left(k_{2} D / 4.05 \mathrm{~F}\right) \exp (4.05 \mathrm{FX} / \mathrm{D})
\end{aligned}
$$

thus:

$$
\mathrm{k}_{1}=\frac{\mathrm{C}_{0}}{1-\exp \left(-4.05 \mathrm{FX}_{0} / \mathrm{D}\right)}
$$


and

$$
\mathrm{k}_{2}=\frac{4.05 \mathrm{C}_{\mathrm{O}} \mathrm{F}}{\mathrm{D}\left[1-\exp \left(4.05 \mathrm{FX}_{\mathrm{O}} / \mathrm{D}\right)\right]}
$$

However, for the purposes of this study, the flux of mercury in the soil is required rather than the concentration. Considering a fixed burial depth $\left(X_{0}\right)$, the flux at any point should be a constant, independent of $x$. Thus, the flux at $x=x_{0}$ in Figure A-1 is:

$$
\phi=-\mathrm{D}\left(\frac{\mathrm{dC}}{\mathrm{dX}}\right)+4.05 \mathrm{FC}
$$

By substituting the appropriate expressions for $\left(\frac{\mathrm{dC}}{\mathrm{dX}}\right)$ and $C$, one obtains:

$$
\phi=\frac{4.05 \mathrm{FC}_{\mathrm{O}}}{1-\exp \left(-4.05 \mathrm{FX}_{\mathrm{O}} / \mathrm{D}\right)}
$$

which is independent of $X$ as required.

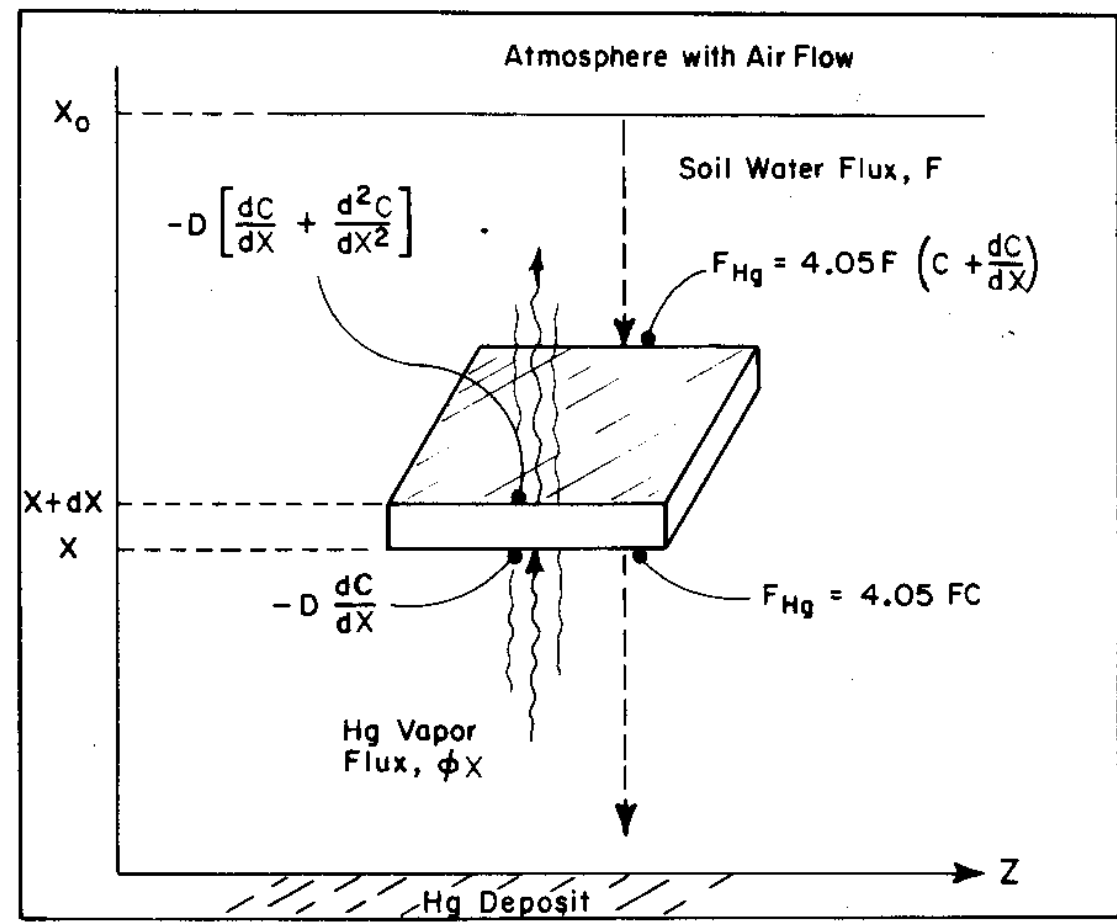

FIGURE A-1. Mathematical Model of Diffusion of Mercury From Soil 1 to the Atmosphere 
However, the expression as written would appear to be undefined for the case when the ground water flux (F) is zero. Though one could formulate an independent expression for $\phi_{\mathrm{F}=0}$, it can also be shown that the above expression can be evaluated as $F$ approaches zero. In order to simplify the expressions:

$$
\beta=\frac{4.05 F}{D}
$$

so that when $F \rightarrow 0$ then $\beta \rightarrow 0$ and

$$
\phi=\frac{D \beta C_{0}}{1-\exp \left(-\beta X_{o}\right)}
$$

Expanding the exponential term in a Taylor expansion one obtains:

$$
\exp \left(-\beta X_{0}\right)=\left(1-\beta X_{0}+\frac{\beta^{2} x_{0}{ }^{2}}{2 !}-\frac{\beta^{3} x_{0}{ }^{3}}{3 !}+\ldots\right),(A-12)
$$

thus,

$$
\begin{aligned}
\phi & =\frac{D B C_{0}}{\left(1-1+\beta X_{0}-\frac{\left(B X_{0}\right)^{2}}{2 !}+\frac{\left(B X_{0}\right)^{3}}{3 !} \ldots\right)} \\
& =\frac{D C_{0}}{\beta X_{0}^{2}} \frac{\beta^{2} X_{0}^{3}}{3 !}
\end{aligned}
$$

which in the limit as $\beta \rightarrow 0$ reduces to

$$
\phi_{B \rightarrow 0}=\frac{\mathrm{DC}_{\mathrm{O}}}{\mathrm{X}_{\mathrm{O}}}
$$

which is the same expression one would obtain for simple diffusion flux. 
In modeling the aqueous flux of mercury to the water table, it is convenient to consider soluble and colloidally suspended mercury independently. The flux of soluble mercury is simply the product of the soil-water flux (F) and the aqueous saturation value $\left(\mathrm{S}^{\circ}\right)$. Since this flux is independent of burial depths, one obtains the total flux $(\phi)$ using the same area taken to be active in atmospheric diffusion:

$$
\phi_{(\mathrm{ng} / \mathrm{hr})}=\left(\mathrm{S}^{\circ}\right) \quad(\mathrm{F}) \quad(\text { Area })
$$

Modeling the flux of colloidally suspended mercury is much more speculative. The following assumptions are required: (1) diffusion of colloidally suspended mercury is nil; (2) streamlining of soil-water flow around mercury nodules allows on $1 y$ the maximum nodule perimeters in the horizontal plane to have effective contact; (3) soil saturation occurs at the nodule perimeter in order to decrease flow resistance; (4) the average soil-water flux at the perimeter is twice the normal flux value; and (5) the colloidal suspension affects only colloids within $0.1 \mathrm{~cm}$ of the nodule perimeter. With these assumptions, one must still estimate the total perimeter of nodules in a given area, to find the total flux due to suspended mercury. 
In the burial ground, the thermodynamically stable form of mercury is the metal, $\mathrm{Hg}^{\circ}$. The stable form was determined by use of Eh-pH diagrams combined with laboratory measurements. Burial ground soil consists primarily of silica, kaolinite, and goethite-hematite. Ground water contains $\sim 3.5 \mathrm{ppm} \mathrm{Cl}^{-}$and $<0.5$ ppm $\mathrm{SO}_{4}{ }^{2-}$, although rainfall contains up to $5 \mathrm{ppm} \mathrm{SO}_{4}{ }^{2-}$. Redox potential of the soil-water system is $0.41-0.47$ volt; $\mathrm{pH}$ ranges from 4.7 to 5.1 .

The logical sequence for performing a study of this type is: (1) Analyze soil and water from the system under study to determine the concentrations of chemically significant species; (2) measure redox potential (Eh) and $\mathrm{pH}$ in the soil-water system under study; (3) consider free energy and redox potential data for the possible compounds of natural systems via an Eh-pH diagram to define regions of thermodynamic stability. Once the stable form is known, it should be possible to design experiments to measure the rate of movement of that form through the soil-water system.

Each of these topics is discussed in the following sections. Methods for plotting Eh-pH diagrams will be treated in detail since the techniques are not familiar to many inorganic chemists, but are practical and extensively used in geochemical studies.

\section{Soil-Water Analyses}

Soil samples representative of the burial ground environment were obtained from a separations area (F) spoil pile. Ground water was obtained from a well $1 / 4$ mile from the burial ground.*

$X$-ray diffraction and Mössbauer spectroscopy data showed that burial ground soil consists of silica, kaolinite, and goethite-hematite, in order of decreasing abundance. These analyses are consistent with spark source mass spectrometric analysis.

Standard water analyses were obtained for as-received ground water and for ground water equilibrated with soil (1 1iter of ground water slurried with $100 \mathrm{~g}$ of soil for $24 \mathrm{hr}$ ). Results are shown in Table B-1.

* Sample obtained at $\sim 25 \mathrm{ft}$ depth front. Well BG-11 in Barnwell formation. 
TABLE B-1

Analyses of Ground Water ${ }^{\alpha}$

$\begin{array}{lll} & \begin{array}{l}\text { As } \\ \text { Received }\end{array} & \begin{array}{l}\text { Equizibrated } \\ \text { With Soit }\end{array} \\ \mathrm{pH} & 5.1 & 4.7 \\ \mathrm{NO}_{3}{ }^{-} & 18 & 17 \\ \mathrm{NO}_{2}{ }^{-} & 0.009 & 0.037 \\ \mathrm{PO}_{4}{ }^{3-} & <0.01 & <0.01 \\ \mathrm{Total}^{3} \mathrm{P} & 0.02 & 0.02 \\ \mathrm{Cl}^{-} & 3.4 & 3.6 \\ \mathrm{SO}_{4}{ }^{2-} & <0.5 & <0.5 \\ \mathrm{CO}_{3}{ }^{2-} & 0.9 & <0.1 \\ \mathrm{NH}_{4}{ }^{+} & 0.04 & 0.01\end{array}$

a. Ions reported as $\mathrm{mg} / \mathrm{l}$.

In natural systems, chlorine and sulfur generally dominate the chemistry of mercury by formation of strong complexes and insoluble compounds. For example, at $0.1 \mathrm{M} \mathrm{CO}_{3}{ }^{2-}, 10^{-6} \mathrm{M}$ total sulfur, and $10^{-6} \mathrm{M}$ total chlorine, carbonate-containing species of mercury are unstable with respect to sulfur- and chlorinecontaining species. ${ }^{8}$ Table $\mathrm{B}-1$ shows that $\mathrm{C}^{-}{ }^{-}$is present in ground water in significant quantity, but that the $\mathrm{SO}_{4}{ }^{2-}$ concentration is very low. However, the $\mathrm{SO}_{4}{ }^{2-}$ concentration in rainfall at the burial ground ranged from 2-5 mg/1 during May 25-28, 1973, and it is believed that sulfur will affect the chemistry of burial ground mercury. Mercuric phosphate is only slightly soluble, but the $\mathrm{PO}_{4}{ }^{3-}$ concentration in ground water is so low, and so little phosphorous is present in soil, that phosphate will not be considered further. 


\section{Redox Potential and $\mathrm{pH}$ Measurements}

Redox potentials measured for the burial ground soil-water system are in the range of those expected for soil-water systems containing dissolved oxygen. A mixture of $10 \mathrm{~g}$ of soil and 100 $\mathrm{ml}$ of ground water was stirred in a beaker for $7 \mathrm{hr}$ while a gas stream containing various amounts of oxygen was bubbled through the mixture. The beaker was tightly stoppered except for a small vent. Potential measurements were made with an Orion Model 96-78 combination platinum electrode. The electrode was calibrated with ZoBel1 solution $\left(1 / 300 \mathrm{M} \mathrm{K}_{4} \mathrm{Fe}(\mathrm{CN})_{6} 3 \mathrm{H}_{2} \mathrm{O}-1 / 300 \mathrm{M} \mathrm{K}_{3} \mathrm{Fe}(\mathrm{CN})_{6}-\right.$ $0.1 \mathrm{M} \mathrm{KC1}$ ) with a stable potential of 0.430 volt at $25^{\circ} \mathrm{C} .{ }^{9} \mathrm{pH}$ was measured with a standard glass electrode. Results are shown in Table B-2.

As expected, the potential increased with increasing partial pressure of oxygen. An approximate expression for the potential of natural systems exposed to air is ${ }^{10}$

$$
\mathrm{Eh}=0.70-0.06 \mathrm{pH}
$$

At $\mathrm{pH} 5.1$, Eh from Equation $\mathrm{B}-1$ is 0.39 volt, in good agreement with the measured value of 0.42 volt.

TABLE B-2

Eh and pH Measurements - Burial Ground Soil-Water Sys tem ${ }^{a}$
$\% \mathrm{O}_{2}$
Eh, vozt pH
$1(99 \% \mathrm{He})$
0.416
5.0
21 (Air)
0.421
5.1
100
0.476
4.8

a. $10 \mathrm{~g}$ soil, $100 \mathrm{ml}$ ground water, $7 \mathrm{hr}$ equilibration.

\section{Consideration of Free Energy and Redox Potential Data}

In this section, methods and data used to construct Eh-pH diagrams for mercury are presented. (The treatment is essentially that given in Solutions, Minerals and Equilibria by Garrels and Christ; ${ }^{11}$ more details can be found in this excellent reference. 
Diagrams are shown for the measured concentrations of chlorine and sulfur, and also for higher concentrations of chlorine and sulfur in order to illustrate the change in stability regions with increasing ionic concentration. Conditions existing in the burial ground are shown as shaded areas on the Eh-pH diagrams.

The methylated mercury species, $\mathrm{CH}_{3} \mathrm{Hg}^{*}$ and $\left(\mathrm{CH}_{3}\right)_{2} \mathrm{Hg}$, are not thermodynamically stable and are not considered in this equilibrium treatment. ${ }^{12}$ The possible existence of these species in non-equilibrium conditions in the Burial Ground will be discussed later.

\section{Construction of Eh-pH Diagrams}

The general approach for construction of Eh-pH diagrams is to write reactions between species of interest in terms of hydrogen ions and electrons. The European sign convention is used in geochemical literature, i.e., the opposite of the convention used in standard American books such as Latiner's Oxidation Potentials ${ }^{13}$ and Lewis and Randall's Thermodynamics. ${ }^{14}$

$$
\begin{aligned}
& \text { Equations are written as } \\
& \text { Reduced state } \rightarrow \text { Oxidized state }+\mathrm{ne}^{-}
\end{aligned}
$$

where $\mathrm{n}$ is the number of electrons involved in the half-reaction.

The corresponding half-cell potential is given by

$$
\mathrm{Eh}=\mathrm{E}^{\circ}+\frac{\mathrm{RT}}{\mathrm{nJ}} \ln \left[\frac{\text { Oxidized state }}{\text { Reduced state }}\right]
$$

where Eh is the half-cell potential relative to the standard hydrogen electrode and $E^{\circ}$ is the standard half-cell potential; other symbols have their usual significance.

For the half-reaction, (at $25^{\circ} \mathrm{C}$ ),

$$
\mathrm{aA}+\mathrm{bB} \rightarrow \mathrm{cC}+\mathrm{dD}+\mathrm{ne}^{-},
$$

Equation $B-3$ yields

$$
E+E^{\circ}+\frac{0.0592}{n} \log \frac{[C]^{c}[D]^{d}}{[A]^{a}[B]^{b}}
$$

Free energy ( $F$ ) and potential data are related by

$$
\Delta F^{\circ}=+n F E^{\circ}
$$

where $F=23.06$ when $\Delta \mathrm{F}^{\circ}$ is in $\mathrm{kcal}$ and $\mathrm{E}^{\circ}$ is in volts.

$$
-32-
$$


For normal, near-surface geochemical problems, calculations are made for $25^{\circ} \mathrm{C}$ and 1 atmosphere total pressure. Activities of pure solids and liquids are taken to be unity, and the activity of a gas phase is assumed equal to its partial pressure (in atm).

The upper limit (oxidizing environment) of water stability is given by the equilibrium between water and $\mathrm{O}_{2}$, as shown in Equation B-7.

$$
2 \mathrm{H}_{2} \mathrm{O} \rightarrow \mathrm{O}_{2}+4 \mathrm{H}^{+}+4 \mathrm{e}^{-}
$$

For the upper 1imit, $P\left(\mathrm{O}_{2}\right)=1 \mathrm{~atm}$ and

$$
E h=E^{0}+\frac{0.0592}{4} \log \left[\mathrm{H}^{+}\right]^{4}
$$

or $E h=E^{\circ}-0.0592 \mathrm{pH}$

The value of $\mathrm{E}^{\circ}$ at $25^{\circ} \mathrm{C}$ is +1.23 volt; ${ }^{13}$ thus

$$
\mathrm{Eh}=1.23-0.0592 \mathrm{pH}
$$

The top line on all Eh-pH diagrams is given by Equation B-9.

Similarly, the lower limit (reducing environment) of water stability is given by Equations B-10 thru B-12. Presence of water is implicit in the term $\mathrm{H}^{+}$(aq).

$$
\begin{aligned}
& \mathrm{H}_{2}(\mathrm{~g}) \rightarrow 2 \mathrm{H}^{+}(\mathrm{aq})+2 \mathrm{e}^{-} \\
& \mathrm{Eh}=\mathrm{E}^{\circ}-0.0592 \mathrm{pH} \\
& \mathrm{Eh}=-0.0592 \mathrm{pH}
\end{aligned}
$$

The bottom line on all Eh-pH diagrams is given by Equation B-12.

It is of interest to note that the potential of natural systems containing oxygen rarely, if ever, approaches that given by Equation B-9, and is usually 0.6 volt lower (see Equation $B-1)$. The reason is that reduction of oxygen to water proceeds rapidly to the intermediate $\mathrm{H}_{2} \mathrm{O}_{2}$, but then proceeds slowly because the $0-0$ bond must be broken. ${ }^{5}$ In addition, traces of heavy metal ions in solution catalyze oxidation of $\mathrm{H}_{2} \mathrm{O}_{2}$ back to $\mathrm{O}_{2}$, establishing reversibility of the $\mathrm{H}_{2} \mathrm{O}_{2}$ couple. As a result of these two factors, the $\mathrm{H}_{2} \mathrm{O}_{2}$ concentration attains some steady-state value, and oxidation processes are controlled by the couple

$$
\begin{aligned}
& \mathrm{H}_{2} \mathrm{O}_{2} \rightarrow \mathrm{O}_{2}+2 \mathrm{H}^{+}+2 \mathrm{e}^{-} \\
& \mathrm{Eh}=0.682-0.0592 \mathrm{pH}+0.0296 \log \frac{\left[\mathrm{O}_{2}\right]}{\left[\mathrm{H}_{2} \mathrm{O}_{2}\right]}
\end{aligned}
$$


For Equation $B-1$ to be strictly valid, $\left[\mathrm{O}_{2}\right] /\left[\mathrm{H}_{2} \mathrm{O}_{2}\right]$ would be 4.0 . This value seems inordinately low in view of the fact that $\mathrm{H}_{2} \mathrm{O}_{2}$ is only an intermediate and is at steady-state with catalytic destruction agents. There is disagreement in the literature ${ }^{16}$ on the value of $\left[\mathrm{O}_{2}\right] /\left[\mathrm{H}_{2} \mathrm{O}_{2}\right]$, but the principle of peroxide control seems well established.

Application of Eh-pH Calculations to Mercury in Burial Ground

Eh-pH calculations were made for systems with $3.5 \mathrm{ppm}$ chlorideno sulfate (consistent with Table B-1), 10 ppm chloride - 10 ppm sulfate, and $100 \mathrm{ppm}$ chloride - $100 \mathrm{ppm}$ sulfate to illustrate the effect of increasing the ionic content of ground water. Under these conditions, the possible stable forms of mercury are $\mathrm{Hg}$, $\mathrm{Hg}_{2} \mathrm{Cl}_{2}, \mathrm{HgCl}_{2}, \mathrm{HgS}$, and $\mathrm{HgO}$. As will be shown, simple oxidation of $\mathrm{Hg}$ to $\mathrm{Hg}_{2}{ }^{2+}(\mathrm{aq})$ or $\mathrm{Hg}^{2+}$ (aq) does not occur because oxidation to $\mathrm{Hg}_{2}{ }^{2+}$ (aq) occurs at 0.789 volt, ${ }^{17}$ higher than the potential at which $\mathrm{Hg}_{2} \mathrm{Cl}_{2}$ or $\mathrm{HgO}$ are formed. Data for $\mathrm{Eh}-\mathrm{pH}$ diagrams are given in Table $\mathrm{B}-3$.

For cases in which $\mathrm{SO}_{4}{ }^{2-}$ was present, calculations were first made to determine stability regions for the various sulfur species in order to determine which species would equilibrate with $\mathrm{Hg}$.

TABLE B-3

Data for Mercury Eh-pH Diagrams

\begin{tabular}{llll} 
Compound or Ion & State & \multicolumn{1}{c}{$\begin{array}{l}\Delta F^{\circ} \text { 298, } \\
\text { keal/mole }\end{array}$} & Reference \\
$\mathrm{HgS}$ & $\mathrm{s}$ & -12.1 & 18 \\
$\mathrm{HgO}$ & $\mathrm{s}$ & -14.0 & 18 \\
$\mathrm{Hg}_{2} \mathrm{Cl}_{2}$ & $\mathrm{~s}$ & -50.35 & 18 \\
$\mathrm{HgCl}_{2}$ & $\mathrm{~s}$ & -42.7 & 18 \\
$\mathrm{H}_{2} \mathrm{~S}^{-}$ & aq & -6.54 & 19 \\
$\mathrm{HS}^{-}$ & aq & 3.01 & 19 \\
$\mathrm{SO}_{4}{ }^{2-}$ & aq & -177.34 & 19 \\
$\mathrm{HSO}_{4}{ }^{-}$ & aq & -179.94 & 19 \\
$\mathrm{H}_{2} \mathrm{O}^{-}$ & liq & -56.69 & 13 \\
$\mathrm{Cl}^{-}$ & & & \\
& aq & -31.35 & 20
\end{tabular}


Elemental sulfur can exist only in a fairly narrow region of the diagram. Details of the sulfur calculations are given in the discussion of sulfur chemistry in soil that follows; results are shown in Figure $B-1$. The equilibrium lines in Figure $B-1$, except for the region of $S^{\circ}$ stability, are independent of total $S$ concentration.

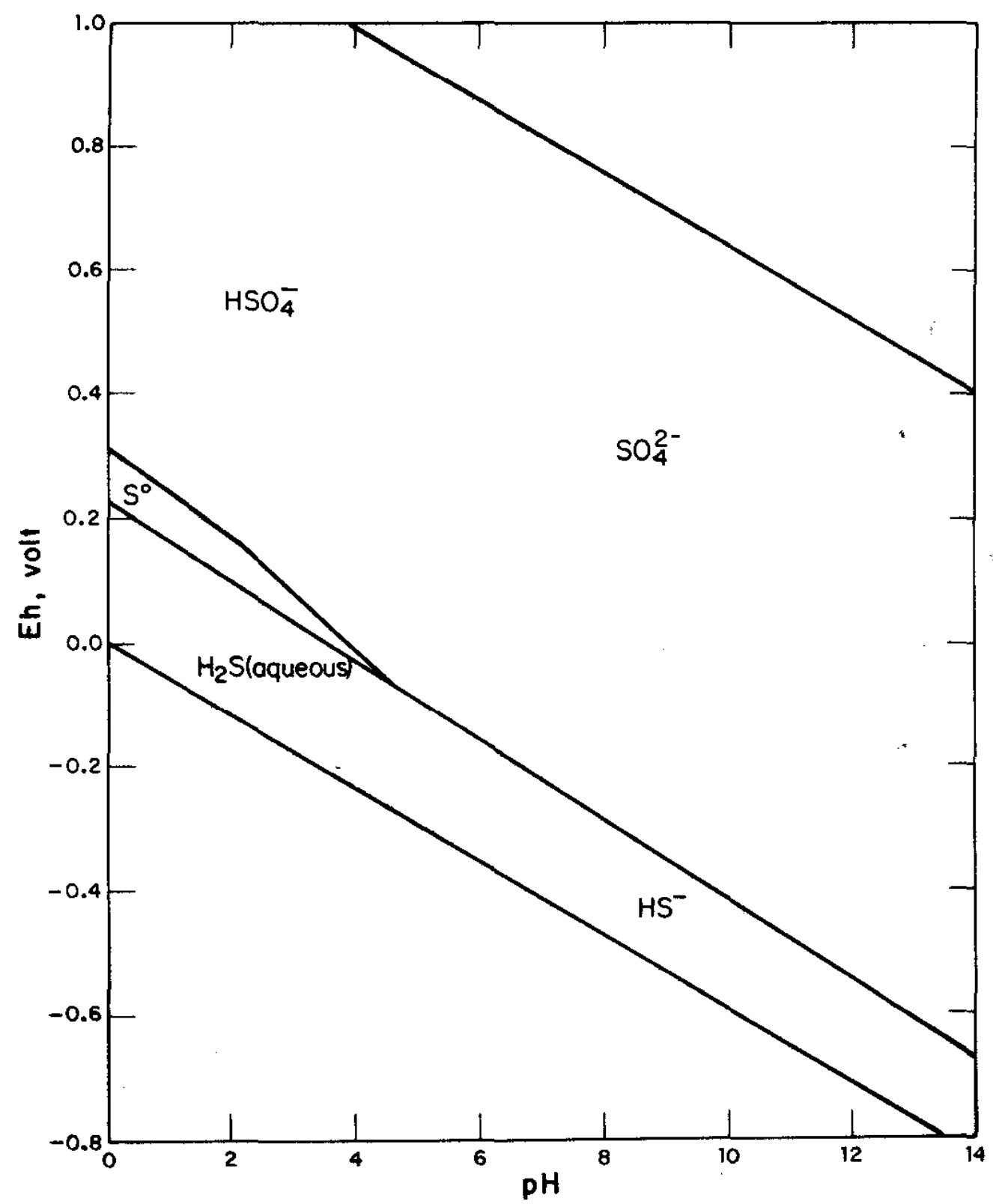

FIGURE B-1. Eh-pH Diagram for Aqueous Systems Containing Sulfur 
Conversion of $\mathrm{HgCl}_{2}$ to $\mathrm{HgO}$ is not a redox reaction. The $\mathrm{pH}$ at which conversion occurs is calculated as shown below.

$$
\begin{aligned}
& \mathrm{HgCl}_{2}+\mathrm{H}_{2} \mathrm{O} \rightarrow \mathrm{HgO}+2 \mathrm{H}^{+}+2 \mathrm{Cl}^{-} \\
& \Delta \mathrm{F}^{0}=-14.0+2(-31.35)+42.7+56.69 \\
& =22.69 \mathrm{kcal} \\
& =-\mathrm{RT} \ln \mathrm{K} \\
& =-1.364 \log \mathrm{K} \text { at } 25^{\circ} \mathrm{C} \\
& \therefore \log K=-16.63 \\
& \therefore K=\left[\mathrm{H}^{+}\right]^{2}\left[\mathrm{Cl}^{-}\right]^{2}=10^{-16.63} \\
& {\left[\mathrm{H}^{+}\right]=\frac{10^{-8.31}}{\left[\mathrm{Cl} 1^{-}\right]}} \\
& \text {At } 10 \mathrm{ppm} \mathrm{Cl}^{-},\left[\mathrm{Cl}^{-}\right]=2.82 \times 10^{-4} \\
& {\left[\mathrm{H}^{+}\right]=\frac{10^{-8.31}}{10^{-3.55}}=10^{-4.76}} \\
& \mathrm{pH}=4.76 \\
& \mathrm{HgS}+4 \mathrm{H}_{2} \mathrm{O} \rightarrow \mathrm{Hg}+\mathrm{SO}_{4}{ }^{2-}+8 \mathrm{H}^{+}+6 \mathrm{e}^{-} \\
& \Delta \mathrm{F}^{\circ}=-177.34+12.1+4(56.69) \\
& =61.5 \mathrm{kcal} \\
& E=\frac{61.5}{(6)(23.06)}+\frac{0.0592}{6} \log \left[\mathrm{SO}_{4}{ }^{2-}\right]\left[\mathrm{H}^{+}\right]^{8} \\
& =0.444-\frac{0.0592}{6} \log \left(1.04 \times 10^{-4}\right)-\frac{(8)(0.059)}{6} \mathrm{pH} \\
& =0.405-0.0789 \mathrm{pH}
\end{aligned}
$$




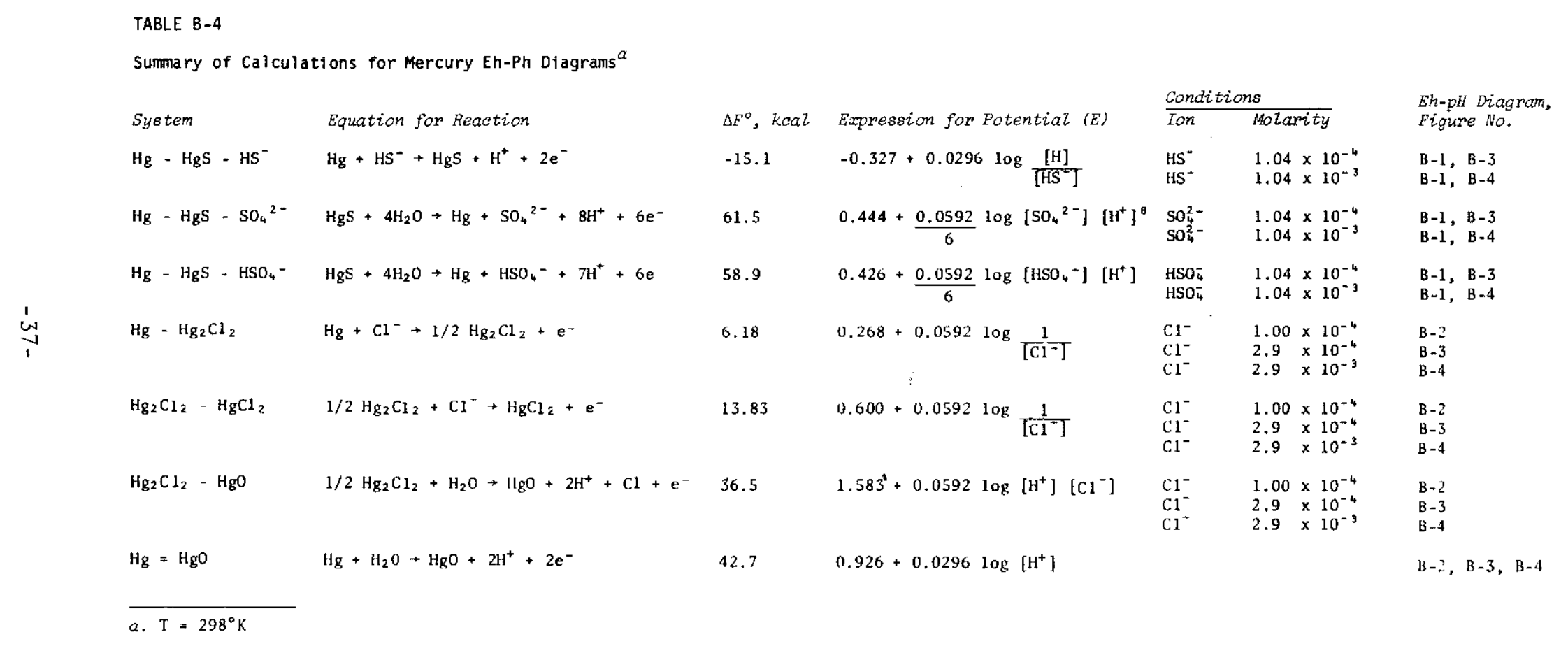


Equations listed in Table B-4 are plotted in Figures B-2-4. Burial ground conditions ( $\mathrm{Eh}=0.41-0.47$ volt, $\mathrm{pH}-4.7-5.1$ ) are also shown. Figure B-2 shows that elemental $\mathrm{Hg}$ is the thermodynamically stable form of mercury in the Burial Ground. When mercury escapes its containment, it will remain as a pool in the ground. Figures $\mathrm{B}-3$ and $\mathrm{B}-4$ indicate that the $\mathrm{Cl}^{-}$content of ground water must increase considerably for $\mathrm{Hg}_{2} \mathrm{Cl}_{2}$ to form. If the $\mathrm{pH}$ of ground water increased, Eh would decrease with the slope given in Equation $\mathrm{B}-1$ and burial ground conditions would move further into the $\mathrm{Hg}$ stability region. An unlikely decrease in $\mathrm{pH}$ below 4.7 would favor formation of very insoluble $\mathrm{Hg}_{2} \mathrm{Cl}_{2}$.

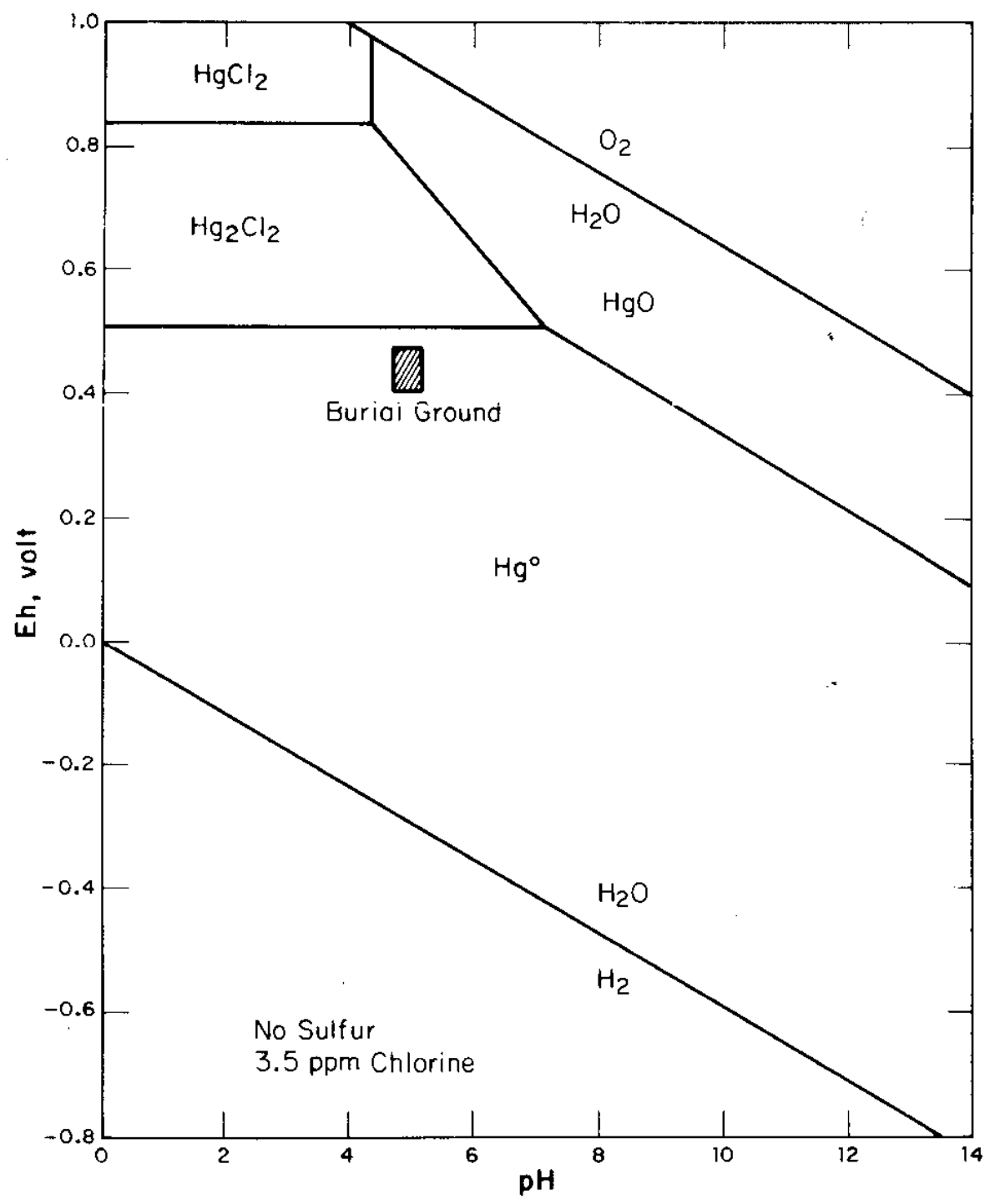

FIGURE B-2. Eh-pH Diagram for Aqueous Systems of Mercury Containing $3.5 \mathrm{ppm}$ Chlorine 


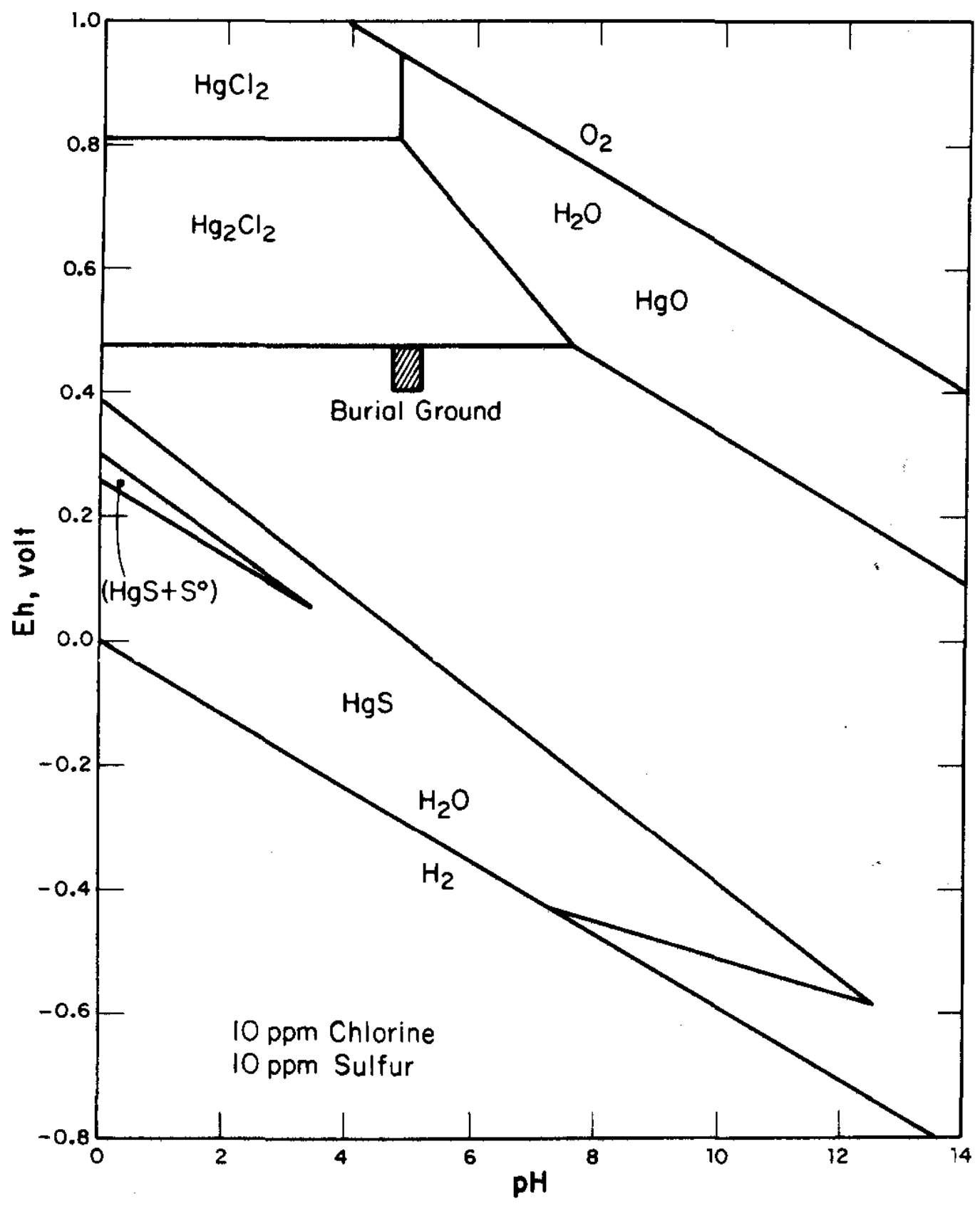

FIGURE B-3. Eh-pH Diagram for Aqueous Systems of Mercury Containing $10 \mathrm{ppm}$ Chlorine and $10 \mathrm{ppm}$ Sulfur 


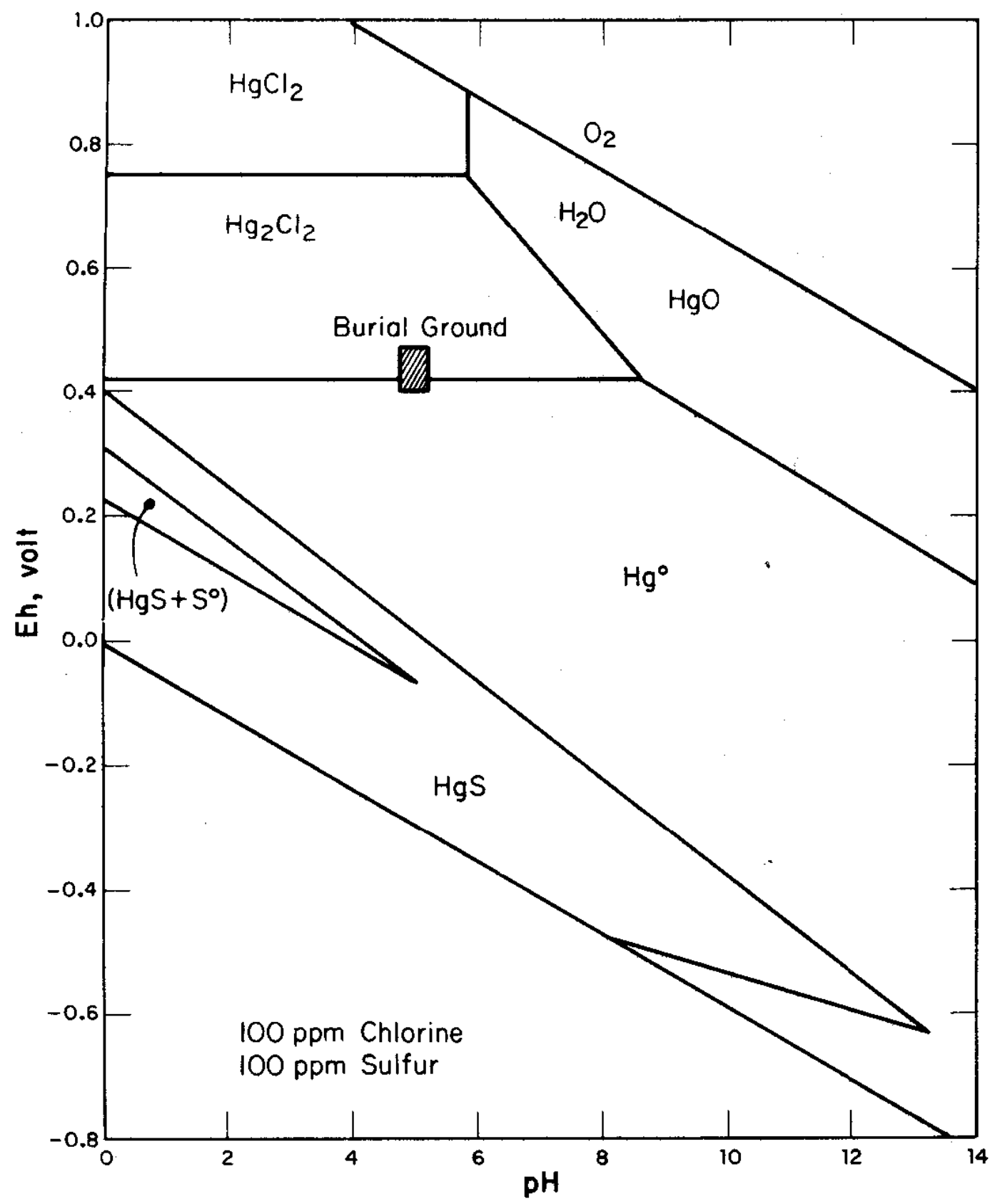

FIGURE B-4. Eh-pH Diagram for Aqueous Systems of Mercury Containing $100 \mathrm{ppm}$ Chlorine and $100 \mathrm{ppm}$ Sulfur 
Sulfur Chemistry in Soil

In aqueous systems at ambient temperature, the stable forms of sulfur are $\mathrm{S}^{2-}, \mathrm{HS}^{-}, \mathrm{H}_{2} \mathrm{~S}, \mathrm{~S}, \mathrm{HSO}_{4}^{-}$, and $\mathrm{SO}_{4}{ }^{2-} .2 \mathrm{I}$ Equilibria between these species were used to plot Figure $\mathrm{B}-1$. Equations are listed below.

$$
\begin{gathered}
\mathrm{HS}^{-}-\mathrm{H}_{2} \mathrm{~S} \\
\mathrm{~K}_{\mathrm{H}_{2} \mathrm{~S}}=\frac{\left[\mathrm{H}^{+}\right]\left[\mathrm{HS}^{-}\right]}{\left[\mathrm{H}_{2} \mathrm{~S}\right]}=10^{-7} \\
\therefore \frac{\left[\mathrm{HS}^{-}\right]}{\left[\mathrm{H}_{2} \mathrm{~S}\right]}=1 \text { at } \mathrm{pH} 7
\end{gathered}
$$

$\mathrm{HS}^{-}-\mathrm{S}^{2-}$

$$
\begin{aligned}
& \mathrm{K}_{\mathrm{HS}^{-}}=\frac{\left[\mathrm{H}^{+}\right]\left[\mathrm{S}^{2-}\right]}{\left[\mathrm{HS}^{-}\right]}=10^{-14} \\
& \therefore \frac{\left[\mathrm{S}^{2-}\right]}{\left[\mathrm{HS}^{-}\right]}=1 \text { at } \mathrm{pH} 14
\end{aligned}
$$

$\mathrm{H}_{2} \mathrm{~S}-\mathrm{HSO}_{4}{ }^{-}$

$$
\begin{aligned}
& \mathrm{H}_{2} \mathrm{~S}(\mathrm{aq})+4 \mathrm{H}_{2} \mathrm{O} \rightarrow \mathrm{HSO}_{4}^{-}+9 \mathrm{H}^{+}+8 \mathrm{e}^{-} \\
& \mathrm{Eh}=0.290-0.0666 \mathrm{pH} \text {, when }\left[\mathrm{HSO}_{4}^{-}\right]=\left[\mathrm{H}_{2} \mathrm{~S}\right]
\end{aligned}
$$

$\mathrm{H}_{2} \mathrm{~S}-\mathrm{SO}_{4}{ }^{2-}$

$$
\begin{aligned}
& \mathrm{H}_{2} \mathrm{~S}(\mathrm{aq})+4 \mathrm{H}_{2} \mathrm{O} \rightarrow \mathrm{SO}_{4}{ }^{2-}+1 \mathrm{OH}^{+}+8 \mathrm{e}^{-} \\
& \mathrm{Eh}=0.303-0.0740 \mathrm{pH} \text {, when }\left[\mathrm{SO}_{4}{ }^{2-}\right]=\left[\mathrm{H}_{2} \mathrm{~S}\right]
\end{aligned}
$$

$\mathrm{HS}^{-}-\mathrm{SO}_{4}{ }^{2-}$

$$
\begin{aligned}
& \mathrm{HS}^{-}+4 \mathrm{H}_{2} \mathrm{O} \rightarrow \mathrm{SO}_{4}{ }^{2-}+9 \mathrm{H}^{+}+8 \mathrm{e}^{-} \\
& \mathrm{Eh}=0.252-0.0666 \mathrm{pH}, \text { when }\left[\mathrm{SO}_{4}{ }^{2-}\right]=\left[\mathrm{HS}^{-}\right]
\end{aligned}
$$

$\mathrm{S}^{2-}-\mathrm{SO}_{4}{ }^{2-}$

$$
\begin{aligned}
& \mathrm{S}^{2-}+4 \mathrm{H}_{2} \mathrm{O} \rightarrow \mathrm{SO}_{4}{ }^{2-}+8 \mathrm{H}^{+}+8 \mathrm{e}^{-} \\
& \mathrm{Eh}=0.148-0.0592 \mathrm{pH}, \text { when }\left[\mathrm{SO}_{4}{ }^{2-}\right]=\left[\mathrm{S}^{2-}\right]
\end{aligned}
$$


$\mathrm{HSO}_{4}{ }^{-}-\mathrm{SO}_{4}{ }^{2-}$

$$
\begin{gathered}
\mathrm{K}_{\mathrm{HSO}_{4}}{ }^{-}=\frac{\left[\mathrm{H}^{+}\right]\left[\mathrm{SO}_{4}{ }^{2-}\right]}{\left[\mathrm{HSO}_{4}{ }^{-}\right]}=10^{-1.9} \\
\frac{\left[\mathrm{SO}_{4}{ }^{2-}\right]}{\left[\mathrm{HSO}_{4}{ }^{-}\right]}=1 \text { at } \mathrm{pH} 1.9
\end{gathered}
$$

The stability region for elemental sulfur is a function of total sulfur concentration. Calculations were made for $1.04 \times 10^{-4} \mathrm{M}$ total sulfur (equivalent to $10 \mathrm{ppm} \mathrm{SO}_{4}{ }^{2-}$ ) and for $1.04 \times 10^{-3} \mathrm{M}$ total sulfur $\left(100 \mathrm{ppm} \mathrm{SO}_{4}{ }^{2-}\right)$.

$\mathrm{H}_{2} \mathrm{~S}-\mathrm{S}$

$$
\begin{aligned}
& \mathrm{H}_{2} \mathrm{~S}(\mathrm{aq}) \rightarrow \mathrm{S}+2 \mathrm{H}^{+}+2 \mathrm{e}^{-} \\
& \mathrm{Eh}=0.260-0.0592 \mathrm{pH}, \text { with } 10 \mathrm{ppm} \text { sulfur } \\
& \mathrm{Eh}=0.230-0.0592 \mathrm{pH}, \text { with } 100 \mathrm{ppm} \text { sulfur }
\end{aligned}
$$

$\mathrm{HS}^{-}-\mathrm{S}$

$$
\begin{aligned}
& \mathrm{HS}{ }^{-} \rightarrow \mathrm{S}+\mathrm{H}^{+}+2 \mathrm{e}^{-} \\
& \text {Eh }=0.053-0.0296 \mathrm{pH} \text {, with } 10 \mathrm{ppm} \text { sulfur } \\
& \text { Eh }=0.023-0.0296 \mathrm{pH} \text {, with } 100 \mathrm{ppm} \text { sulfur } \\
& \mathrm{S}-\mathrm{SO}_{4}{ }^{2-} \\
& \mathrm{S}+4 \mathrm{H}_{2} \mathrm{O} \rightarrow \mathrm{SO}_{4}{ }^{2-}+8 \mathrm{H}^{+}+6 \mathrm{e}^{-} \\
& \text {Eh }=0.318-0.0789 \mathrm{pH} \text {, with } 10 \mathrm{ppm} \text { sulfur } \\
& \text { Eh }=0.328-0.0789 \mathrm{pH} \text {, with } 100 \mathrm{ppm} \text { sulfur } \\
& \mathrm{S}-\mathrm{HSO}_{4}^{-} \\
& \mathrm{S}+4 \mathrm{H}_{2} \mathrm{O}+\mathrm{HSO}_{4}^{-}+7 \mathrm{H}^{+}+6 \mathrm{e}^{-} \\
& \text {Eh }=0.299-0.0691 \mathrm{pH} \text {, with } 10 \mathrm{ppm} \text { sulfur } \\
& \text { Eh }=0.309-0.0691 \mathrm{pH} \text {, with } 100 \mathrm{ppm} \text { sulfur }
\end{aligned}
$$


REFERENCES

1. E. C. Childs and N. C. George. "Soil Geometry and SoilWater Equilibria." Discuss. Faraday Soc. 3, 78 (1948).

2. E. C. Childs. "Ihe Movement of Soil Water." Endeavour 23, 84 (1964).

3. T. L. Lyon and H. D. Buckman. The Nature and Properties of Soils. McMillan Co., New York (1949).

4. V. I. Muscat, T. J. Vickers, and Anders Andren. "Simple and Versatile Atomic Fluorescence System for the Determination of Nanogram Quantities of Mercury." Anaz. Chem. 44; 218 (1972).

5. V. I. Muscat and T. J. Vickers. "Determination of Nanogram Quantities of Mercury by the Reduction-Aeration Method and Atomic Fluorescence Spectrophotometry." Anal. Chemica Acta $57,23(1971)$.

6. E. Onat. "Solubility Studies of Metallic Mercury in Pure Water at Various Temperatures." J. Inorg. Nucl. Chem. 36, 2029 (1974).

7. P. N. Cheremisinoff and Y. H. Habib. "Cadmium, Chromium, Lead, Mercury: A Plenary Account for Water Pollution.:" Water Sewage Works 119, 74 (1972).

8. Harris H. Schmitt, Editor. Equilibrium Diagrams for Minerals at Low Temperature and Pressure. Harvard University (1964).

9. C. E. ZoBe1l. "Oxidation-Reduction Potential of Marine Sediments." Bulz. Am. Assoc. Petroleum Geol. 30, 477 (1946).

10. R. M. Garrels and C. L. Christ. Solutions, Minerals, and Equilibria. p 137, Harper and Row, New York (1965).

11. R. M. Garrels and C. L. Christ. Solutions, Minerals, and Equilibria. p 173, Harper and Row, New York (1965).

12. J. D. Hem. "Chemical Behavior of Mercury in Aqueous Media." p 21 in Mercury in the Environment, U. S. Geological Survey Professional Paper 713 (1970). 
13. W. M. Latimer. Oxidation Potentials. p 39, Prentice-Ha11, Inc., New York (1952).

14. G. N. Lewis. Thermodynamics. McGraw-Hill, New York (1961).

15. Motoaki Sato. "Oxidation of Sulfide Ore Bodies. I. Geochemical Environments in Terms of Eh and pH." Econ. Geol. 55,928 (1960).

16. W. G. Breck. "Reciox Potentials by Equilibration."

J. Marine Res. 30, 121 (1972).

17. W. M. Latimer. Oxidation Potentials. p 182, Prentice-Hal1 Inc., New York (1952).

18. J. D. Hem. "Chemical Behavior of Mercury in Aqueous Media." p 62 in Mercury in the Environment, U. S. Geological Survey Professional Paper 713 (1970).

19. W. M. Latimer. Oxidation Potentials. p 72, Prentice-Hal1, Inc., New York (1952).

20. W. M. Latimer. Oxidation Potentials. p 54, Prentice-Ha11, Inc., New York (1952).

21. R. M. Garrels and C. L. Christ. Solutions, Minerals, and Equilibria. p 213, Harper and Row, New York (1965). 